\title{
Inferring Stratigraphic Position of Fossil Vertebrates from the Niobrara Chalk of Western Kansas
}

\author{
S. Christopher Bennett \\ College of Chiropractic, University of Bridgeport, Bridgeport, CT 06601-2449
}

\begin{abstract}
The stratigraphy of the Smoky Hill Chalk Member of the Niobrara Chalk of western Kansas is well understood as a result of the work of Hattin (1982) and Stewart (1988). Marker units identified by Hattin (1982) allow quick determination of the stratigraphic position of a specific outcrop. This study demonstrates that it is now possible to determine the stratigraphic positions of specimens from locality data, thus permitting one to infer stratigraphic position of specimens collected long ago. This technique is particularly useful in the upper half of the Smoky Hill Chalk Member, where biostratigraphy is not informative. The stratigraphic distribution of the type skulls of the pterosaur Pteranodon is examined as an example of the procedure, which in turn demonstrates that the procedure can have the power to reject hypotheses. Inferring stratigraphic positions of fossil vertebrates may be useful in further studies of the large collections of fossil vertebrates from the Smoky Hill Chalk Member. In addition, examination of the stratigraphic distribution of outcrops of the Smoky Hill Chalk Member in western Kansas suggests that most of the fossil vertebrates collected from the member came from a rather restricted stratigraphic interval between Marker Units 15 and 20.
\end{abstract}

\section{Introduction}

The Smoky Hill Chalk Member of the Niobrara Chalk of western Kansas is famous for the very large number of fossil vertebrates it has produced. The collection of fossil vertebrates from the Smoky Hill Chalk Member was begun in earnest by O. C. Marsh and the Yale College Scientific Expedition in 1870. That expedition and subsequent ones by Marsh and colleagues in 1871 and 1872 were so successful in the discovery of abundant remains of fish, mosasaurs, pterosaurs, birds, plesiosaurs, and turtles that Marsh hired professional collectors, including B. F. Mudge and S. W. Williston, to work the Niobrara Chalk for him each year through 1879. During this 10-year period, Marsh amassed the largest and one of the most important collections of Niobrara vertebrates. Since the 1870's, collecting of Niobrara vertebrates has been almost continuous. H. T. Martin of The University of Kansas collected many specimens, providing the core of the large collection at The University of Kansas, and selling specimens to many other museums. George F. Sternberg collected for many years and, like H. T. Martin, sold specimens widely but saved much of the best material for the Sternberg Memorial Museum [later renamed the Fort Hays State Museum (FHSM) and now called the Sternberg Museum of Natural History] in Hays, Kansas. In addition, many other individuals have made small but good collections.
The majority of fossil vertebrates were collected before the stratigraphy of the Niobrara Chalk was adequately understood, and their stratigraphic positions are unknown. The most that the collectors recorded was whether the specimen was from gray (or blue) shale or yellow chalk. The gray-yellow dichotomy is not particularly useful because it is largely a weathering phenomenon (Williston, 1897; Miller, 1968), and often the color change is found at different levels in the same outcrop.

Most studies of fossil vertebrates from the Smoky Hill Chalk Member have suffered from a lack of stratigraphic information, and authors have often had to rely on the fact that exposures along the eastern end of the outcrop area in Ellis County are low in the Smoky Hill Chalk Member, while those of the western end in Logan County are higher. Bardack (1965) located many of the old localities, but at the time the stratigraphy was not sufficiently well known to determine stratigraphic positions of those localities with any precision. The purpose of this report is to show that it is now possible to determine the stratigraphic positions of specimens from locality data. Although precise locality data are best, often even rather vague locality data are sufficient to determine the stratigraphic position of a specimen.

It is important to note that almost all of the Yale Peabody Museum (YPM) collection was collected in the 1870's, before the old Wallace County was divided into Wallace and St. John counties in 1881. St. John County 
was changed to Logan County in 1885 (Elias, 1931). Bardack (1965) noted that the present Logan County was formerly called St. John County, but did not mention that it was formerly a part of a larger Wallace County. The Niobrara Chalk is not widely exposed in the modern Wallace County. Many specimens in the YPM and other collections are listed as being collected in Wallace County, but almost all of them are from what is now Logan County, and a few are probably from Gove County (see below).

\section{Stratigraphy}

The stratigraphy of the Smoky Hill Chalk Member of the Niobrara Chalk in western Kansas is now well understood. Hattin (1982) described the stratigraphy of the Smoky Hill Chalk Member and identified 23 marker units. Hattin's marker units are the completion and perfection of the pioneering work of Russell (1929), and they allow quick determination of the stratigraphic position of an outcrop in the field. The invertebrate biostratigraphy of the Smoky Hill Chalk Member was examined by Miller (1968) and Hattin (1982). Stewart (1988) showed that vertebrates can also be useful for biostratigraphy in the Smoky Hill Chalk Member. Biostratigraphic zonations based on inoceramids and species of the fish Protosphyraena divide the Smoky Hill Chalk Member into four zones, but biostratigraphic zonations do not allow subdivision of the upper half of the Smoky Hill Chalk Member. This is unfortunate because the upper half of the Smoky Hill Chalk Member has produced the majority of fossil vertebrates. Stewart (1988) noted that this is not because the lower half is unfossiliferous (fossils may actually be more common in the lower parts), but rather that fossils from the upper parts were more intensively collected. Letters sent to O. C. Marsh by his collectors S. W. Williston and E. W. Guild (alias E. S. Field) indicate that they concentrated on the upper part because they believed the hunting better, particularly in regard to the birds and pterosaurs for which O. C. Marsh paid the most money. Whatever the reason, most fossil vertebrates have been collected from the upper part of the Smoky Hill Chalk Member, and biostratigraphy is of no use in determining the relative stratigraphic position of these specimens. Therefore, it is necessary to rely on the stratigraphic marker units.

Hattin (1982) and Russell (1929) both designated marker units that allow quick determination of stratigraphic position, and in some instances both authors used the same markers. Marker units identified by Russell (1929) are based almost entirely on bentonite sequences and are lettered, while those identified by Hattin (1982) also include units of unusual lithology and are numbered. In addition to the marker units, many other bentonites are readily recognizable and traceable in the field. These are particularly useful in correlating small outcrop areas with larger outcrops nearby. In this paper Hattin's marker units are used when possible, but Russell's Marker Unit H between Marker Units 17 and 18 also is used because it is readily identifiable and widely exposed.

If the exact locality of a specimen is known, one need only compare the exposure at the locality with the composite stratigraphic column of Hattin (1982). When the exact locality is not known or the exposure at the particular locality is of limited vertical extent and between marker units, a number of nearby outcrops are examined. Despite some regional variations, the bentonite sequences are remarkably uniform across the outcrop area in western Kansas. This uniformity makes possible the precise correlation of outcrops.

\section{Pteranodon}

The utility of this method for inferring stratigraphic position from locality data was examined with the pterosaur Pteranodon. Pteranodon was a large pterosaur with a wingspan ranging from 3-6 m (9-20 ft). Known from roughly 1,200 specimens, it was an important part of the fauna of the Western Interior Seaway and was the most common tetrapod after the mosasaurs Platecarpus, Clidastes, and Tylosaurus. The postcranial skeleton is of no taxonomic value at the species level, and although Pteranodon occurs in two size classes, this reflects sexual dimorphism in size rather than specific differences (Bennett, 1991, 1992). The skull, on the other hand, has been used to distinguish species. Five nominal species of Pteranodon are based on skulls, and they differ in the size and shape of the cranial crest and the angle between the occiput and the palate. The type skulls of Pteranodon longiceps, P. marshi, and P. eatoni have a reclined occiput that is plesiomorphic for pterodactyloids, while those of $P$. sternbergi and $P$. walkeri have a more upright occiput. In the absence of stratigraphic information, it was hypothesized that the cranial morphology evolved from a reclined occiput to an upright occiput, and that a single species or lineage of Pteranodon was present in the Smoky Hill Chalk Member. If this were the case, one would not expect the two morphologies to co-occur, and skulls with reclined occiputs should be stratigraphically lower than those with upright occiputs.

To test this hypothesis, it was necessary to determine the stratigraphic positions of the type skulls. The localities of these specimens of Pteranodon, as well as nearby outcrops, were visited and stratigraphic columns measured. Localities in Logan and Gove counties are shown in fig. 1, and the stratigraphic columns are listed in the Appendix. These columns were then compared to the composite stratigraphic column of Hattin (1982), and stratigraphic positions of the outcrops were determined. Using the stratigraphic columns and any other available information about the position or locality of the specimens, it was possible to determine the stratigraphic position or 


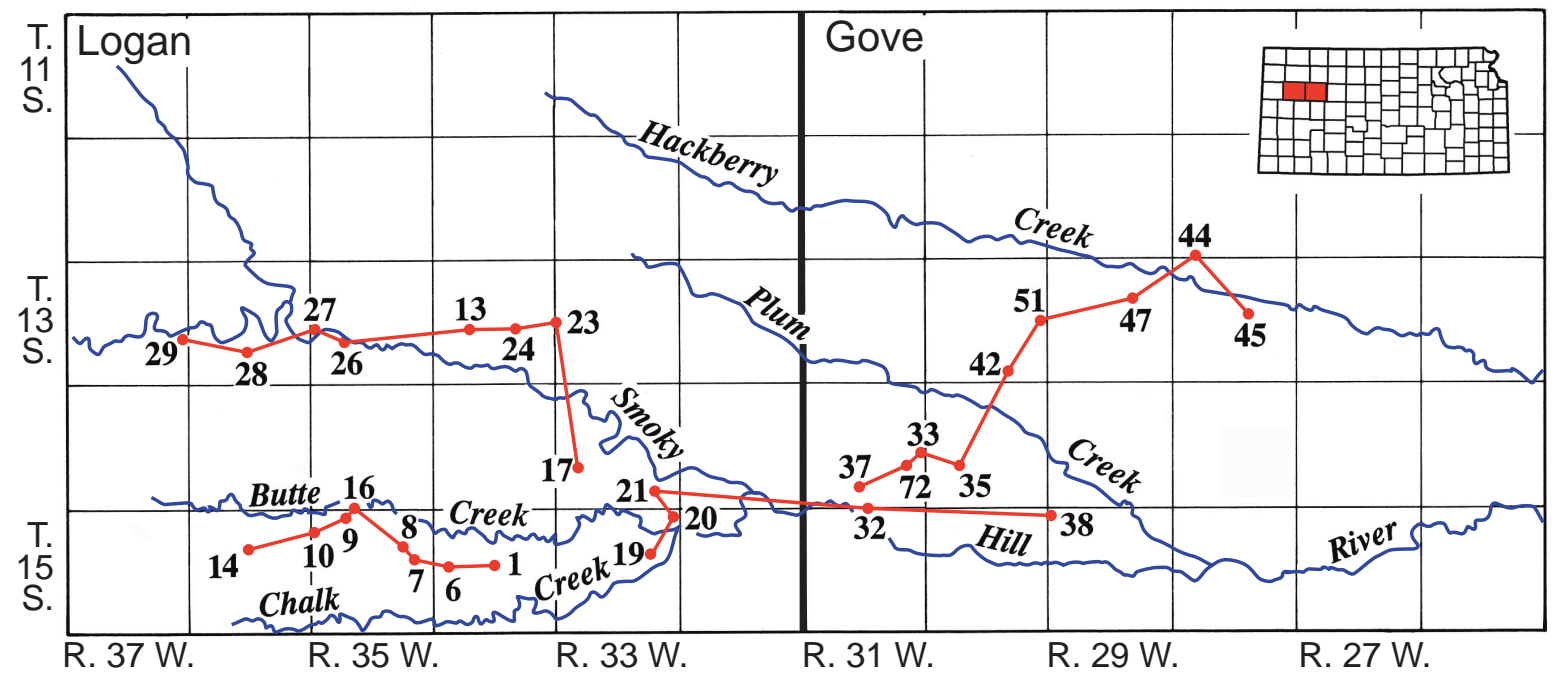

FIGURE 1. Map of Logan and Gove counties, Kansas, showing the localities where stratigraphic columns were measured. Red lines between localities show their order in figs. 2 and 5-7.

range for these type specimens of Pteranodon. The five nominal species are discussed below in the order in which they were named.

Pteranodon longiceps (YPM 1177) - According to the YPM catalog, this skull was collected May 2, 1876, by S. W. Williston from "near Smoky Hill River, Wallace Co." Williston's 1876 field notebook in the YPM archives lists the locality as "3 mi. NE of Monument Rocks in fine yellow chalk," and a map prepared by S. W. Williston (also in the YPM archives) shows that the specimen was collected on the west side of the first drainage east of Monument Rocks and about $3 \mathrm{mi}$. $(4.8 \mathrm{~km})$ north of the Smoky Hill River. This is in Gove County, not in Wallace or Logan, and is approximately Locality 72 . Comparison of this locality with Locality 37 to the southwest and Localities 33 and 35 to the northeast shows that Locality 72 ranges from $4 \mathrm{~m}$ (13 ft) below Marker Unit $15 \mathrm{up}$ almost to Marker Unit 16 (fig. 2). At Locality 72, the chalk is gray from $1.5 \mathrm{~m}(5 \mathrm{ft})$ above Marker Unit 15. The fact that the skull was collected in yellow chalk while the chalk in the lower parts of the exposure is gray suggests that the skull came from at least $2 \mathrm{~m}(6.5 \mathrm{ft})$ above Marker Unit 15 and below Marker Unit 16.

Pteranodon sternbergi (FHSM VP 339)—This skull was collected by G. F. Sternberg from sec. 12, T. 8 S., R. 22 W., Graham County, Kansas, about $1 \mathrm{mi}(1.6 \mathrm{~km})$ west of Bogue and between Highway 24 and the south fork of the Solomon River (Bardack, 1965). An outcrop in the NE sec. 12, T. 8 S., R. 22 W., Graham County, is very small and difficult to measure, but it has abundant remains of Inoceramus (Volviceramus) grandis. The presence of $I$. (V.) grandis indicates that the specimen is from Stewart's (1988) Biostratigraphic Zone A or B and quite low in the Smoky Hill Chalk Member. Marker Unit 4 is visible near the top of the approximately $8 \mathrm{~m}(26 \mathrm{ft})$ of exposure and also is exposed in other nearby outcrops. Although the exact horizon of the type skull is unknown, it must have come from approximately Marker Unit 4 or a short distance below.

Pteranodon marshi (YPM 2594)—This skull was collected July 20, 1877, by S. W. Williston from "near Smoky Hill River, Wallace Co." (according to field labels and YPM catalog). A chronological listing of all specimens collected by the field party indicates that they had been moving east from Russell Springs for a number of weeks and collected a mosasaur on Plum Creek in western Gove County, also on July 20. The skull was presumably collected somewhere near there. Localities 33, 35, and 42 are on either side of Plum Creek and indicate that exposures on Plum Creek are between Marker Units 16 and 19 (fig. 2). Therefore, the skull was probably collected between those marker units.

Pteranodon walkeri (FHSM VP 221) - This skull was collected by G. F. Sternberg from $2 \mathrm{mi}$. (3.2 km) northeast of Penokee, Sec. 13, T. 8 S., R. 24 W., Graham County, Kansas (Bardack, 1965). Locality 55 in sec. 13, T. 8 S., R. $24 \mathrm{~W}$. has Marker Unit 18 in the middle of a 10-m (32-ft) exposure, and Localities 54 and 60 to the southwest and northeast, respectively, are both a little lower (fig. 3). In this case the exact locality is known and, although the exact horizon is not known, the type skull must have come from within $5 \mathrm{~m}(16 \mathrm{ft})$ above or below Marker Unit 18.

Pteranodon eatoni (YPM 1179)—This skull was collected in 1875 by E. W. Guild (alias E. S. Field) from the "Smoky Hill River, near Castle Rock, Trego Co." (according to field labels and YPM catalog). In an earlier report of this work (Bennett, 1990), I took "near Castle Rock" to mean within a couple of miles and concluded 


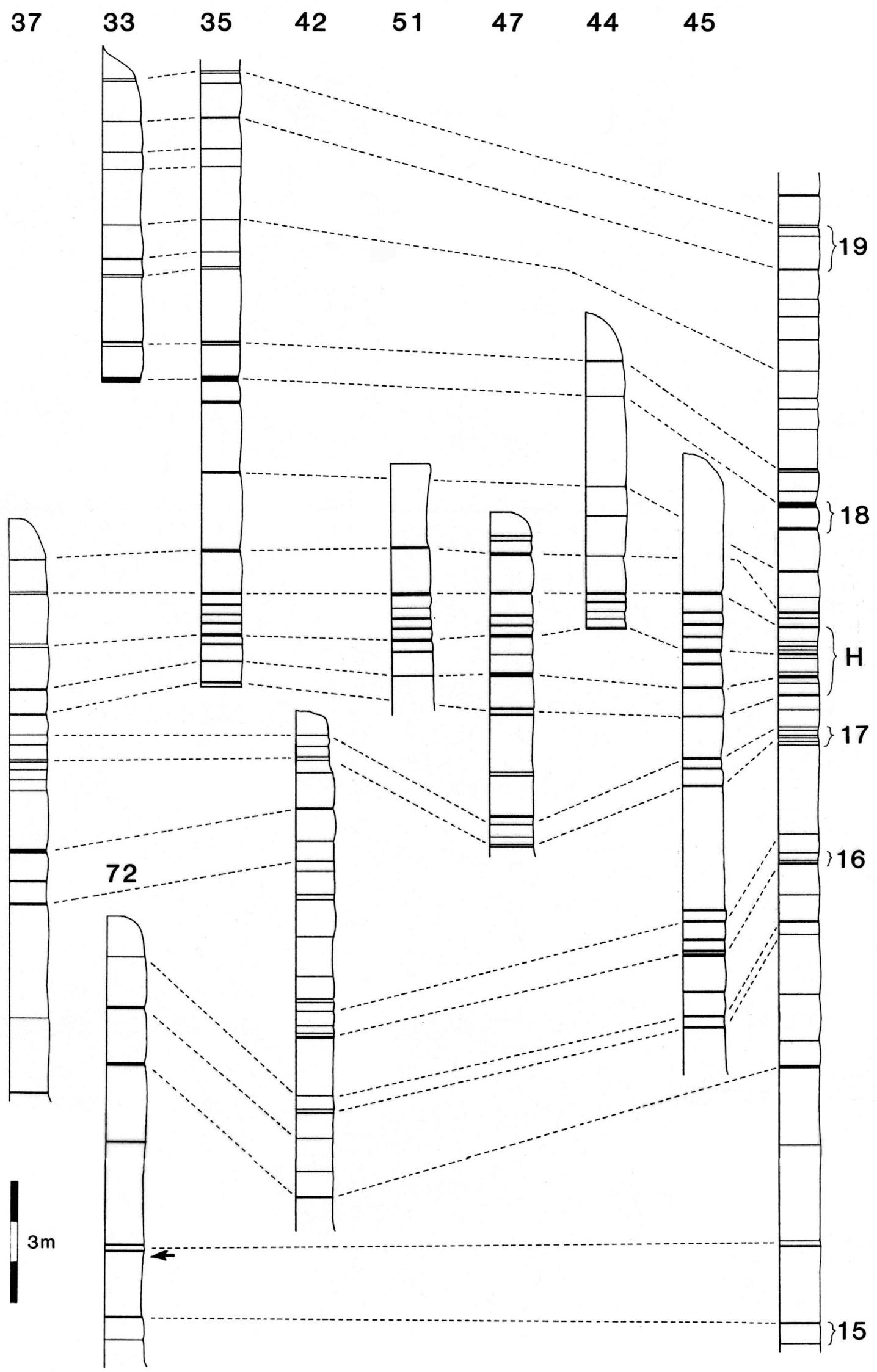

FIGURE 2. Correlation of stratigraphic columns of localities in western Gove County, Kansas. Black bands indicate bentonites, seams, and in a few instances a change in lithology; white indicates chalk. Localities are numbered across the top and arranged in order from west to east. The unnumbered column at right is the composite stratigraphic column from Hattin (1982). Hattin's marker units are identified by the numbers at right, and Russell's (1929) marker unit $\mathrm{H}$ is also indicated. The relative vertical position of different stratigraphic columns in the figure is not significant. The arrow by Locality 72 indicates the change from gray to yellow chalk. 
that the skull was collected between Marker Units 8 and

13. However, the fact that it was collected in Trego

County should have suggested a greater distance. Analysis

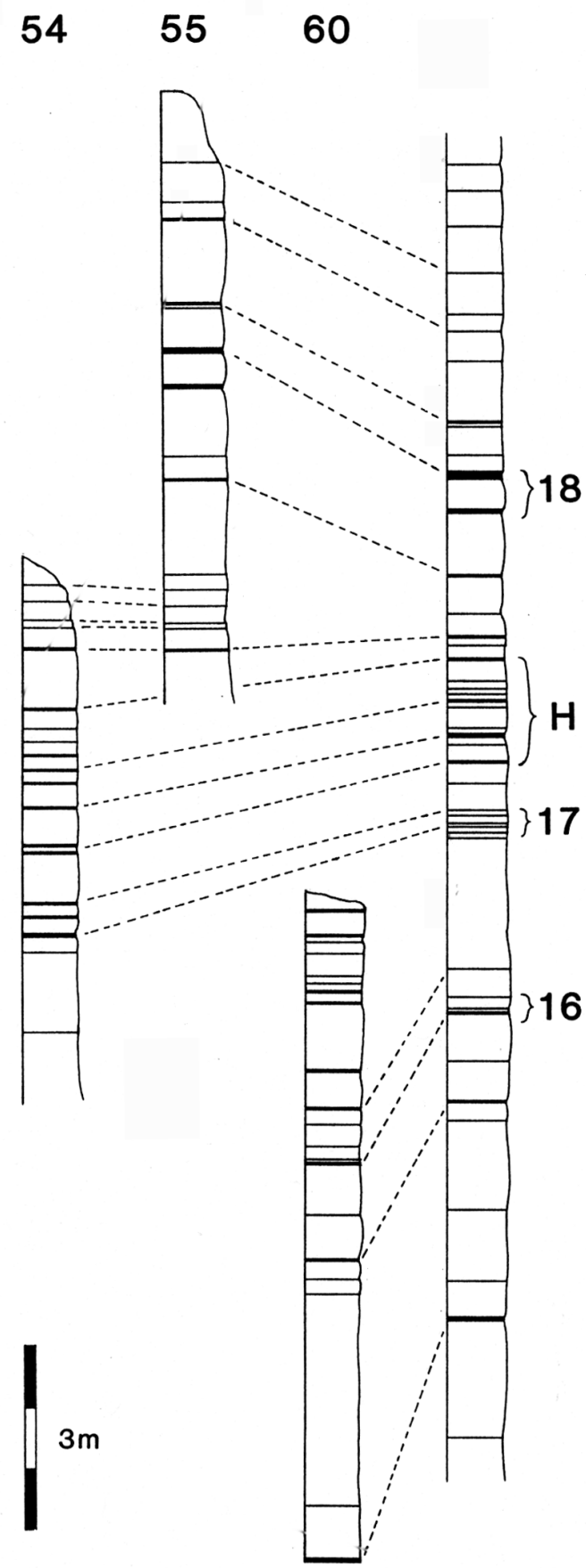

FIGURE 3. Correlation of stratigraphic columns of localities in Graham County, Kansas. Black bands indicate bentonites, seams, and in a few instances a change in lithology; white indicates chalk. Localities are numbered across the top and arranged in order from west to east. The unnumbered column at right is the composite stratigraphic column from Hattin (1982). Hattin's marker units are identified by the numbers at right, and Russell's (1929) marker unit H is also indicated. The relative vertical position of different stratigraphic columns in the figure is not significant. of the calcareous nannofossils in the matrix adhering to the specimen indicates that it came from between Marker Unit 4 and 6 (D. Watkins, 1991, personal communication).

Wildcat Canyon in western Trego County and near Castle Rock has exposures ranging from Marker Units 2 to 4, so the range between Marker Units 4 and 6 is reasonable.

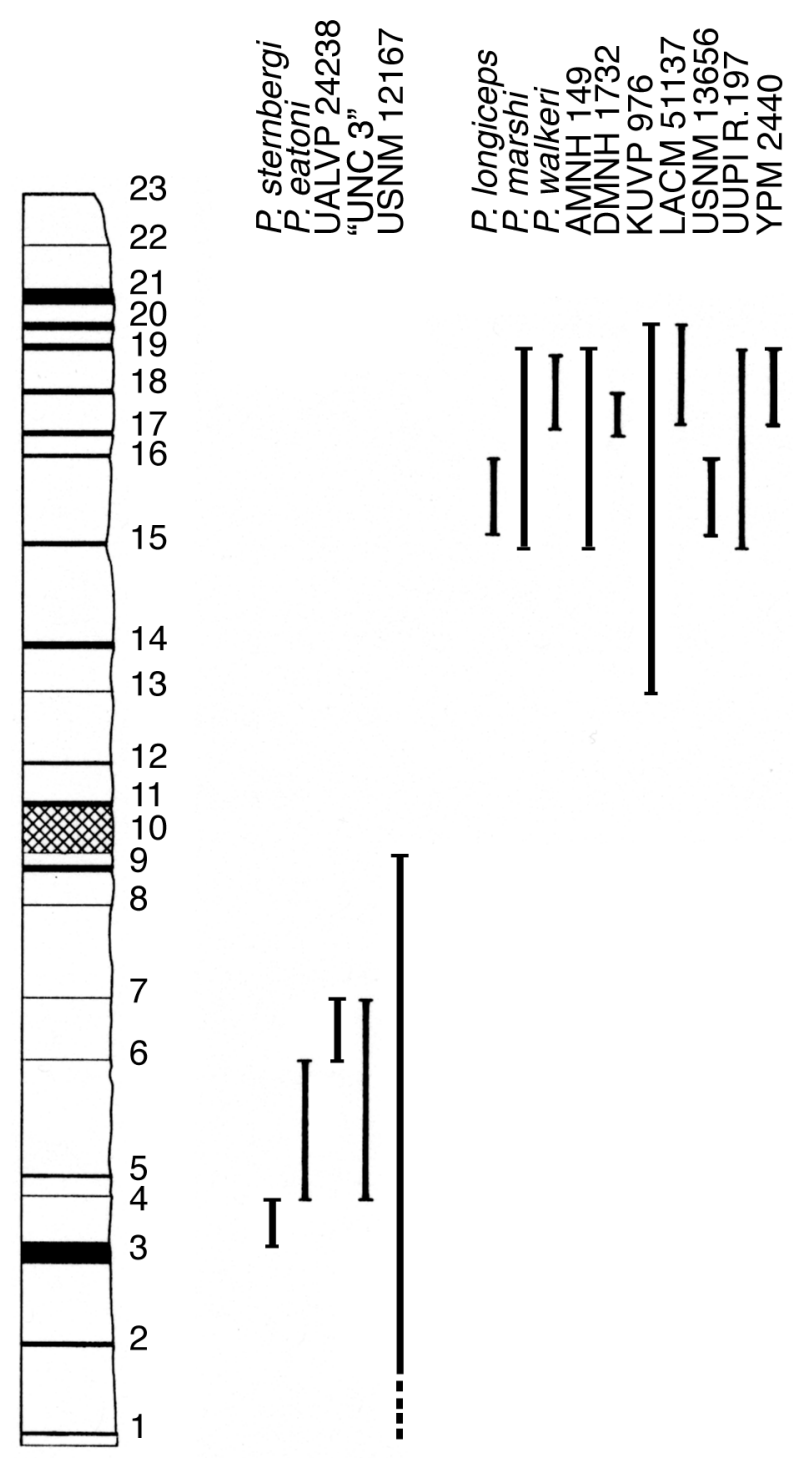

FIGURE 4. Inferred stratigraphic positions or ranges of type and other important specimens of Pteranodon plotted against the composite stratigraphic column from Hattin (1982). Marker units are indicated by black lines or bands, or in the case of Marker Unit 10, the prominent caprock, by cross-hatching. Institutional abbreviations: AMNH, American Museum of Natural History, New York; DMNH, Denver Museum of Natural History; KUVP, Natural History Museum, University of Kansas, Lawrence; LACM, Los Angeles County Museum of Natural History; UALVP, Geology Museum, University of Alberta, Edmonton; "UNC", Uncatalogued specimen (see Bennett, 1991); USNM, U.S. National Museum, Washington, D.C; UUPI, Palaeontological Institute, University of Uppsala, Uppsala, Sweden; YPM, Yale Peabody Museum, New Haven. 


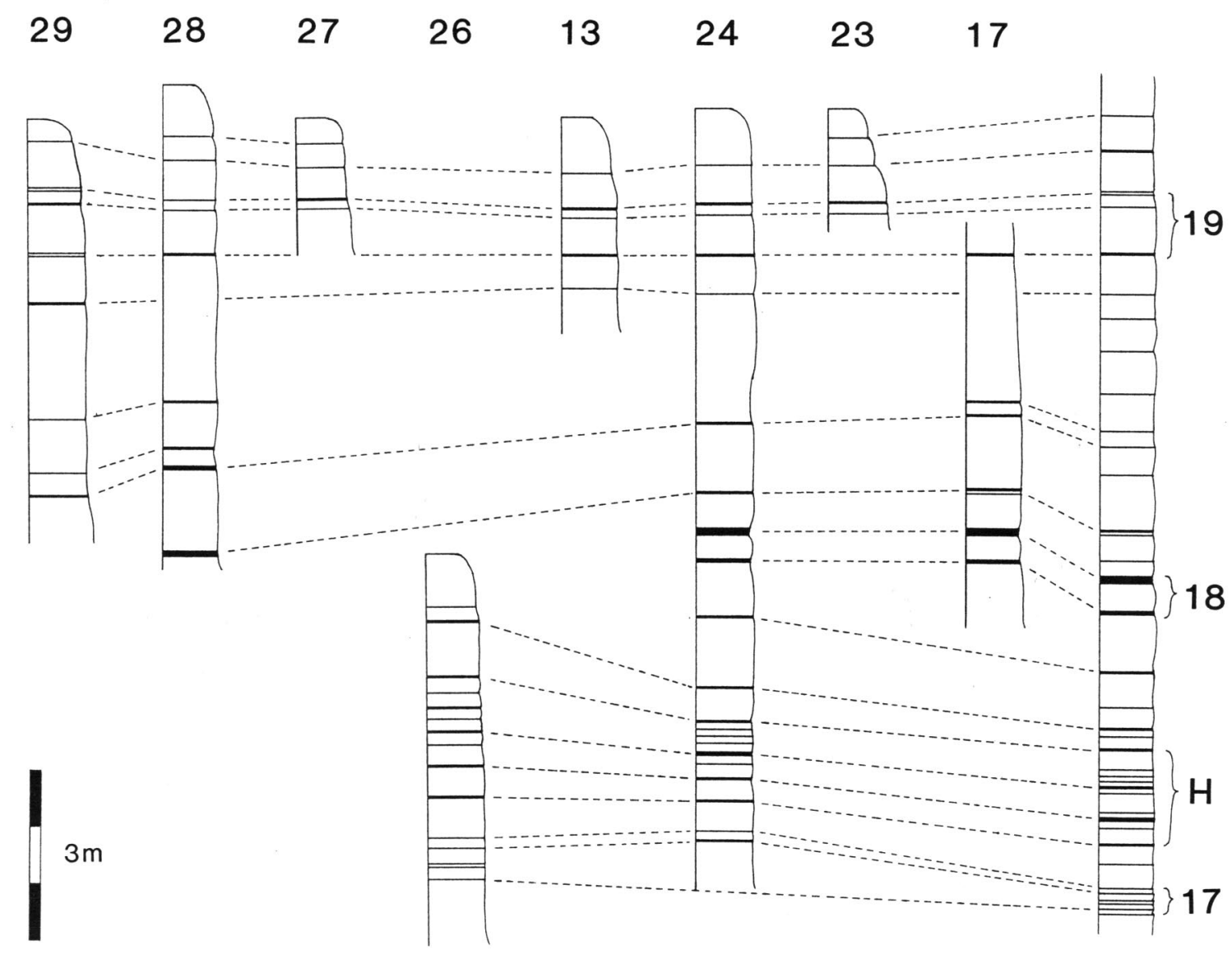

FIGURE 5. Correlation of stratigraphic columns of localities along the Smoky Hill River in Logan County, Kansas. Black bands indicate bentonites, seams, and in a few instances a change in lithology; white indicates chalk. Localities are numbered across the top and arranged in order from west to east. The unnumbered column at right is the composite stratigraphic column from Hattin (1982). Hattin's marker units are identified by the numbers at right, and Russell's (1929) marker unit H is also indicated. The relative vertical position of different stratigraphic columns in the figure is not significant.

A plot of the stratigraphic positions of the type skulls as well as other important specimens (fig. 4) shows that skulls with upright occiputs are found from Marker Unit 3 up to Marker Unit 7 or perhaps 10, while skulls with reclined occiputs occur between Marker Units 13 and 20. Therefore, the two morphologies do not co-occur.

\section{Discussion}

The stratigraphic distribution shows that skulls with upright occiputs occurred only in the lower part of the Smoky Hill Chalk Member and that skulls with reclined occiputs occurred only in the upper part of the Smoky Hill Chalk Member. Because the two morphs do not co-occur, they could be early and late forms of a single evolving species or lineage, but the hypothesis is falsified because the polarity of the crest shape change is the opposite of that which was expected. The two morphs are probably chronospecies of an anagenetically evolving single species lineage that continued throughout the time of deposition of the Smoky Hill Chalk Member.

This study shows that it is possible to determine the stratigraphic positions of specimens from the Smoky Hill Chalk Member from locality data even if they were collected more than 100 years ago. When applied to even a small number of specimens, the procedure can have the power to reject hypotheses.

While determining the stratigraphic positions of other specimens not discussed in this paper, I visited many other localities and measured stratigraphic columns. Additional measured sections covering much of Logan County and part of Gove County are included in figs. 2 and 5-7. The pattern of the exposures is interesting. In the northwestern part of the exposures in Gove County (fig. 2) and much of 

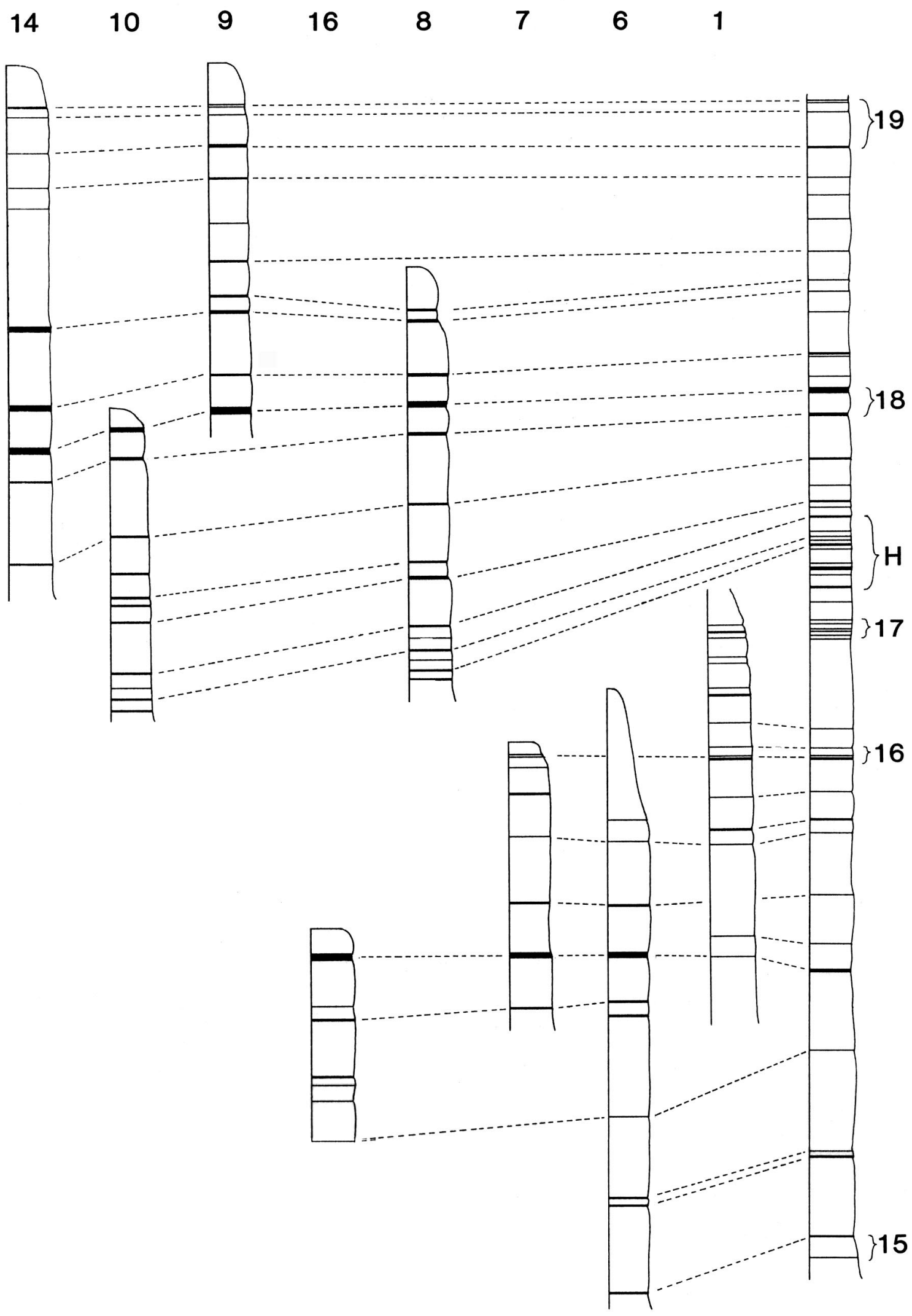

Figure 6. Correlation of stratigraphic columns of localities along Twin Butte Creek in Logan County, Kansas. Black bands indicate bentonites, seams, and in a few instances a change in lithology; white indicates chalk. Localities are numbered across the top and arranged in order from west to east. The unnumbered column at right is the composite stratigraphic column from Hattin (1982). Hattin's marker units are identified by the numbers at right, and Russell's (1929) marker unit H is also indicated. The relative vertical position of different stratigraphic columns in the figure is not significant. 


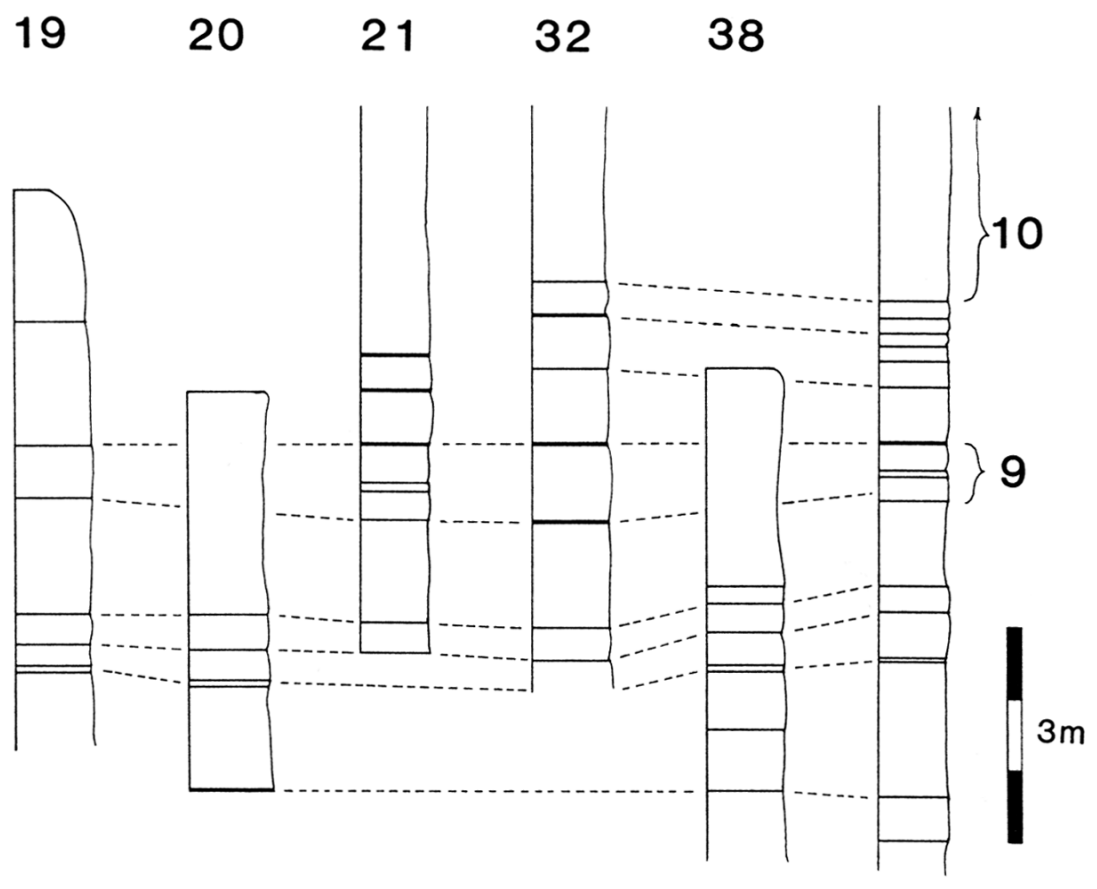

FIGURE 7. Correlation of stratigraphic columns of localities in southeastern Logan and southwestern Gove counties, Kansas. Black bands indicate bentonites, seams, and in a few instances a change in lithology; white indicates chalk. Localities are numbered across the top and arranged in order from west to east. The unnumbered column at right is the composite stratigraphic column from Hattin (1982). Hattin's marker units are identified by the numbers at right. The relative vertical position of different stratigraphic columns in the figure is not significant.

Logan County (figs. 5 and 6) as well as in western Graham County (fig. 3), the interval between Marker Units 15 and 20 is almost exclusively exposed. The interval between Marker Units 10 and 15 is exposed in places in eastern Logan and western Gove counties (Locality 18, Hattin's localities 22 and 23), but the caprock (Marker Unit 10) and the chalk below appear to be more widely exposed in those areas (fig. 7). This may be a result of a bias on my part toward outcrops that are larger and easier to measure; other parts of the Smoky Hill Chalk Member may be extensively exposed but in outcrops that are small in area or thickness and difficult to measure. On the other hand, it is possible that the chalk between Marker Units 10 and 15 and above Marker Unit 20 erodes more easily and is not widely exposed. More study of this question is needed. The apparently biased distribution of exposures suggests that most of the fossil vertebrates collected from the Smoky Hill Chalk Member came from a rather restricted stratigraphic interval between Marker Units 15 and 20. This may have important implications for future studies of fossil vertebrates from the Smoky Hill Chalk Member.

\section{Conclusions}

Hattin (1982) stated that the composite column and marker units make it possible to determine precisely the stratigraphic positions of Smoky Hill Chalk Member outcrops. This paper shows that it is possible to determine the stratigraphic positions of specimens collected long ago. This technique should be useful in studies of other taxa from the Smoky Hill Chalk Member. In addition, this study demonstrates that the marker units of Hattin (1982) make it possible for collectors to determine the stratigraphic positions of specimens. One hundred years ago, Williston (1897, p. 245) wrote, "I need not call the attention of future collectors to the importance of locating the horizon of specimens more accurately than has been done heretofore." For many years after that statement was made, the stratigraphy of the Smoky Hill Chalk Member was only poorly understood. We now have the means to do as Williston suggested, and all future collectors should record horizon and locality as accurately as possible.

\section{Acknowledgments}

J. D. Stewart and O. W. Bonner shared their extensive knowledge of the Smoky Hill Chalk Member. D. Watkins kindly determined the age of samples using calcareous nannoplankton biostratigraphy. D. E. Hattin, J. D. Stewart, and R. L. Kaesler reviewed the manuscript and provided constructive criticism. This work would not have been possible without the generous funding of NSF Dissertation Improvement Grant BSR-700547. 


\section{References}

Bardack, D., 1965, Localities of fossil vertebrates obtained from the Niobrara Formation (Cretaceous) of Kansas: University of Kansas Publications, Museum of Natural History, v. 17, p. 114.

Bennett, S. C., 1990, Inferring stratigraphic position of fossil vertebrates from the Niobrara Chalk of western Kansas; in, Niobrara Chalk Excursion Guidebook, 1990 Annual Meeting, Society of Vertebrate Paleontology, S. C. Bennett, ed.: Kansas Geological Survey, Open-file Report 90-60, p. 43-72.

Bennett, S. C., 1991, Morphology of the Late Cretaceous pterosaur Pteranodon and systematics of the Pterosauria: Unpublished Ph.D. dissertation, University of Kansas, Lawrence, Kansas. xvii +680 p.

Bennett, S. C., 1992, Sexual dimorphism of Pteranodon and other pterosaurs, with comments on cranial crests: Journal of Vertebrate Paleontology, v. 12, p. 422-434.
Elias, M. K., 1931, The geology of Wallace County, Kansas: Kansas Geological Survey, Bulletin 18, 254 p.

Hattin, D. E., 1982, Stratigraphy and depositional environment of Smoky Hill Chalk Member, Niobrara Chalk (Upper Cretaceous) of the type area, western Kansas: Kansas Geological Survey, Bulletin 225, 108 p.

Miller, H. W., 1968, Invertebrate fauna and environment of deposition of the Niobrara Formation (Cretaceous) of Kansas: Fort Hays Studies, New Series, Science Series No. 8, 90 p.

Russell, W. L., 1929, Stratigraphy and structure of the Smoky Hill Chalk in western Kansas: American Association of Petroleum Geologists, Bulletin, v. 13, p. 595-604.

Stewart, J. D 1988, The stratigraphic distribution of Late Cretaceous Protosphyraena in Kansas and Alabama; in, Geology, Paleontology, and Biostratigraphy of Western Kansas-Articles in Honor of Myrl V. Walker, M. E. Nelson, ed.: Fort Hays State University Studies, Third Series, No. 10, p. 80-94.

Williston, S. W., 1897, The Kansas Niobrara Cretaceous: The University Geological Survey of Kansas, v. 2, p. 237-246. 


\section{Appendix: Measured stratigraphic sections at localities in figs. 2, 3, and 5-7.}

Locality 1-W/2 of SW sec. 15, T. 15 S., R. 34 W., Logan County, Kansas. Base at 3,020 ft (920 m). Units 12-16 are Marker Unit 16.

\begin{tabular}{|c|c|c|}
\hline Unit & Description & Thickness (cm) \\
\hline 33 & $\begin{array}{l}\text { Yellow chalk to top } \\
\text { of the outcrop }\end{array}$ & $\sim 100$ \\
\hline 32 & Ferruginous seam & 0.2 \\
\hline 31 & Yellow chalk & 15 \\
\hline 30 & Ferruginous seam & 0.2 \\
\hline 29 & Pale chalk & 3.8 \\
\hline 28 & Ferruginous seam & 0.3 \\
\hline 27 & Yellow chalk & 12 \\
\hline 26 & Ferruginous seam & 0.2 \\
\hline 25 & Yellow chalk & 46 \\
\hline 24 & $\begin{array}{l}\text { Massive white chalk- } \\
\text { forms resistant ledge }\end{array}$ & 15 \\
\hline 23 & Yellow chalk & 56 \\
\hline 22 & $\begin{array}{l}\text { Massive white chalk- } \\
\text { forms slight ledge }\end{array}$ & 16 \\
\hline 21 & Tan silty chalk seam & 0.8 \\
\hline 20 & Massive white chalk & 2 \\
\hline 19 & Yellow chalk & 63.5 \\
\hline 18 & Ferruginous seam & 0.8 \\
\hline 17 & Yellow chalk & 56 \\
\hline 16 & Ferruginous seam & 0.3 \\
\hline 15 & Yellow chalk & 21.5 \\
\hline 14 & Ferruginous seam & 0.2 \\
\hline 13 & Yellow chalk & 7 \\
\hline 12 & Ferruginous seam & 1.5 \\
\hline 11 & Yellow chalk & 86 \\
\hline 10 & Ferruginous seam & 0.3 \\
\hline 9 & Yellow chalk & 76 \\
\hline 8 & $\begin{array}{l}\text { Ferruginous seam- } \\
\text { forms prominent reentrant }\end{array}$ & 1.5 \\
\hline 7 & Yellow chalk & 34 \\
\hline 6 & Ferruginous seam & 0.2 \\
\hline 5 & Yellow chalk & 213 \\
\hline 4 & Ferruginous seam & 0.3 \\
\hline 3 & Yellow chalk & 48 \\
\hline 2 & Ferruginous/gypsiferous seam & 0.8 \\
\hline 1 & Massive yellow chalk & 167 \\
\hline \multicolumn{3}{|c|}{ Total thickness of measured section } \\
\hline
\end{tabular}

Locality 6-S/2 of line between sec. 17 and 18, T. 15 S., R. 34 W., Logan County, Kansas. Base at 3,010 ft $(917 \mathrm{~m})$. Units 1-2 are Marker Unit 15.

\begin{tabular}{|c|c|c|}
\hline Unit & Description & Thickness (cm) \\
\hline 21 & $\begin{array}{l}\text { Yellow chalk to top } \\
\text { of outcrop }\end{array}$ & 305 \\
\hline 20 & Bentonite & 0.6 \\
\hline 19 & Massive chalk & 51 \\
\hline 18 & $\begin{array}{l}\text { Ferruginous seam-locally } \\
\text { expanded to } 2.5 \mathrm{~cm} \text { by selenite }\end{array}$ & 0.6 \\
\hline 17 & Yellow chalk & 147 \\
\hline 16 & $\begin{array}{l}\text { Gypsiferous seam-locally } \\
\text { altered to selenite and may } \\
\text { have local limonitic inclusions }\end{array}$ & 3 \\
\hline 15 & Chalk & 109 \\
\hline 14 & $\begin{array}{l}\text { Bentonite unit- } 2.5 \mathrm{~cm} \text { of } \\
\text { orange to red-brown clay } \\
\text { expanded by gypsum and } \\
\text { iron oxide }\end{array}$ & 12.7 \\
\hline 13 & Chalk & 102 \\
\hline 12 & Bentonite & 3.8 \\
\hline 11 & Chalk & 29 \\
\hline 10 & Bentonite & 3 \\
\hline 9 & Gray chalk & 235 \\
\hline 8 & $\begin{array}{l}\text { Ferruginous seam-locally } \\
\text { expanded to } 1 \mathrm{~cm} \text { by selenite }\end{array}$ & 0.1 \\
\hline 7 & Tan chalk & 185 \\
\hline 6 & Gypsiferous seam & 2 \\
\hline 5 & Tan chalk & 14 \\
\hline 4 & $\begin{array}{l}\text { Bentonite-locally } \\
\text { expanded by selenite }\end{array}$ & 2.5 \\
\hline 3 & Gray chalk & 201 \\
\hline 2 & $\begin{array}{l}\text { Bentonite unit }-1 \mathrm{~cm} \text { of } \\
\text { white clay surrounded by } \\
\text { iron oxide }\end{array}$ & 3 \\
\hline 1 & Light-gray chalk & 46 \\
\hline Total th & s of measured section $\quad 1,455$ & \\
\hline
\end{tabular}


Locality 7-NW sec. 13, T. 15 S., R. 35 W., Logan

County, Kansas. Base at 3,050 ft (930 m). Units 13-

14 are part of Marker Unit 16.

\begin{tabular}{|c|c|c|}
\hline Unit & Description & Thickness (cm) \\
\hline 15 & $\begin{array}{l}\text { Yellow chalk to top } \\
\text { of outcrop }\end{array}$ & 30.5 \\
\hline 14 & $\begin{array}{l}\text { Pale-cream-colored chalk- } \\
\text { in fresh chalk it is an } \\
\text { indistinct } 2.5 \text {-cm seam of } \\
\text { powdery gypsum }\end{array}$ & 6.4 \\
\hline 13 & Yellow chalk & 23 \\
\hline 12 & $\begin{array}{l}\text { Unit-two ferruginous/ } \\
\text { gypsiferous seams } \\
\text { separated by } 0.8-\mathrm{cm} \text { gray chalk }\end{array}$ & 1.4 \\
\hline 11 & Gray chalk & 60 \\
\hline 10 & $\begin{array}{l}\text { Ferruginous seam—locally } \\
\text { produces large limonitic } \\
\text { inclusions up to } 6.5 \mathrm{~cm} \text { thick }\end{array}$ & 1.5 \\
\hline 9 & Gray chalk & 100 \\
\hline 8 & Ferruginous/gypsiferous seam & 0.8 \\
\hline 7 & Gray chalk & 153 \\
\hline 6 & Bentonite & 2.5 \\
\hline 5 & Gray chalk & 114 \\
\hline 4 & $\begin{array}{l}\text { Bentonite unit }-6 \mathrm{~cm} \text { of } \\
\text { gray, yellow, and orange } \\
\text { clay expanded by iron oxide } \\
\text { and gypsum }\end{array}$ & 12.7 \\
\hline 3 & Gray chalk & 117 \\
\hline 2 & Ferruginous/gypsiferous seam & 1.8 \\
\hline 1 & Gray chalk & 61 \\
\hline
\end{tabular}

Locality 8-Butte in NE SE sec. 11, T. 15 S., R. 34 W., Logan County, Kansas, on the north or up side of a fault. Base at 3,100 ft $(945 \mathrm{~m})$. Units 20-22 are Marker Unit 18.

\begin{tabular}{llc}
\hline \hline Unit & \multicolumn{1}{c}{ Description } & Thickness $(\mathbf{c m})$ \\
\hline \multirow{3}{*}{31} & Yellow chalk to the top & $\sim$ \\
& of the outcrop & \\
30 & Ferruginous/gypsiferous seam & 3.2 \\
29 & Yellow chalk & 21
\end{tabular}

Bentonite

6.4

Massive yellow chalk

119

Ferruginous/gypsiferous seam

2.5

Tan chalk

Seam

0.6

Yellow chalk

61

Bentonite unit- $8.5 \mathrm{~cm}$ of

11.4

silty chalk expanded by

gypsum and iron oxide,

forms a major reentrant

Chalk

61

Bentonite

Tan chalk

160

Ferruginous/gypsiferous seam

Massive gray chalk

Ferruginous/gypsiferous

seam-crops out as selenite

Gray chalk

Bentonite

Gray chalk-forms a

rounded cap on outcrop

Bentonite

Pale-tan chalk

Seam

Gray chalk

Ferruginous/gypsiferous seam

Gray chalk

Ferruginous seam

Gray chalk

Bentonite

Gray chalk

Ferruginous seam

Gray chalk

Total thickness of measured section $931.7 \mathrm{~cm}$

Locality 9-Small butte in NE NE sec. 5, T. 15 S., R. 35 W., Logan County, Kansas. Base at 3,090 ft (942 m). Units 1-2 are part of Marker Unit 18 and units 18-22 are Marker Unit 19.

\begin{tabular}{lll}
\hline Unit & Description & Thickness $(\mathrm{cm})$ \\
\hline
\end{tabular}

23 Yellow chalk to top of bluff

Bentonite

Yellow chalk 


\begin{tabular}{|c|c|c|c|c|c|}
\hline 20 & Ferruginous seam & 0.6 & 21 & Chalk & 61 \\
\hline 19 & & 70 & 20 & & 5.7 \\
\hline & cropping out as selenite & & & of red-brown clay between & \\
\hline & lies $44 \mathrm{~cm}$ above bottom & & & powdery gypsum & \\
\hline 18 & Ferruginous/gypsiferous seam & 4.4 & 19 & Gray chalk & 178 \\
\hline 17 & Tan chalk & 2.5 & 18 & Ferruginous/gypsiferous seam & 3.2 \\
\hline 16 & Gypsiferous seam—with & 1 & 17 & Massive yellow chalk & 85 \\
\hline & iron oxide film at bottom & & 16 & Seam—crops out as selenite & 2 \\
\hline 15 & Massive yellow chalk & 71 & 15 & Massive yellow chalk & 55 \\
\hline 14 & Bentonite—crops out as & 3.8 & 14 & Seam—crops out as selenite & 2 \\
\hline & a selenite & & 13 & Massive yellow chalk & 14 \\
\hline 13 & Massive yellow chalk & 105 & 12 & Seam—crops out as selenite & 2 \\
\hline 12 & Ferruginous seam & 0.5 & 11 & Massive yellow chalk & 36 \\
\hline 11 & Yellow chalk—a seam lies & 86 & 10 & Ferruginous/gypsiferous seam & 3.8 \\
\hline & $21 \mathrm{~cm}$ above bottom & & 9 & Yellow chalk-a 1-cm & 117 \\
\hline 10 & Ferruginous/gypsiferous & 2.5 & & gypsiferous seam lies $25 \mathrm{~cm}$ & \\
\hline & seam—crops out as a & & & above the bottom & \\
\hline & selenite ledge & & 8 & Ferruginous/gypsiferous seam & 3.8 \\
\hline 9 & Yellow chalk & 79 & 7 & Gray chalk & 32 \\
\hline 8 & Ferruginous/gypsiferous seam & 2.5 & 6 & Ferruginous/gypsiferous seam & 1.4 \\
\hline 7 & Yellow chalk & 32 & 5 & Gray chalk & 25 \\
\hline 6 & Bentonite unit $-1.1 \mathrm{~cm}$ of & 5.1 & 4 & Ferruginous/gypsiferous seam & 2 \\
\hline & waxy gray clay expanded by & & 3 & Gray chalk & 23 \\
\hline & gypsum and iron oxide & & 2 & Ferruginous seam & 2 \\
\hline 5 & Yellow chalk & 142 & 1 & Gray chalk & 30 \\
\hline 4 & Bentonite unit- $1.2 \mathrm{~cm}$ of & 2.5 & & & \\
\hline & gray clay expanded by & & Total & ess of measured section 693.9 & \\
\hline & gypsum and iron oxide & & & & \\
\hline 3 & Yellow chalk & 76 & & & \\
\hline 2 & $\begin{array}{l}\text { Bentonite unit-gray, } \\
\text { olive, and tan clays, } \\
\text { expanded by iron oxide }\end{array}$ & 14 & $\begin{array}{r}\text { Loca } \\
\mathrm{T} . \\
2,\end{array}$ & $\begin{array}{l}\text { 3-North end of line betwee } \\
\text { R. } 34 \text { W., Logan County, K } \\
(890 \mathrm{~m}) \text {. Units } 4-8 \text { are Mar }\end{array}$ & $\begin{array}{l}\text { ec. } 20 \text { and } 21 \text {, } \\
\text { sas. Base at } \\
\text { r Unit } 19 .\end{array}$ \\
\hline 1 & Chalk & 91 & Unit & Description & Thickness $(\mathrm{cm})$ \\
\hline Total t & ss of measured section $\quad 841.9$ & & 11 & Yellow chalk to top of & $\sim$ \\
\hline & & & & the outcrop & \\
\hline Local & $\mathbf{0}-\mathrm{W} / 2$ of line between sec. & and 7, T. 15 S., & 10 & Seam & 0.3 \\
\hline & I., Logan County, Kansas. B & at $3,150 \mathrm{ft}$ & 9 & Yellow chalk & 60 \\
\hline & . Units 20-22 are Marker & & 8 & Bentonite & 3.4 \\
\hline & & & 7 & Yellow chalk & 14 \\
\hline Unit & Description & Thickness (cm) & 6 & Seam & 0.5 \\
\hline & & & 5 & Yellow chalk & 63.5 \\
\hline 23 & Chalk to top of the outcrop & $\sim$ & 4 & Unit—two ferruginous & 2.2 \\
\hline 22 & Bentonite unit $-7.5 \mathrm{~cm}$ & 10 & & seams, the lower $0.2 \mathrm{~cm}$ & \\
\hline & of gray clay, expanded by & & & and upper $0.5 \mathrm{~cm}$ thick, & \\
\hline & iron oxide and gypsum & & & separated by chalk & \\
\hline
\end{tabular}




$\begin{array}{ll}3 & \text { Yellow chalk } \\ 2 & \text { Ferruginous seam } \\ 1 & \text { Yellow chalk }\end{array}$

Total thickness of measured section $291.2 \mathrm{~cm}$

Locality 14-SE SW sec. 10, T. 15 S., R. 36 W., Logan County, Kansas. Base at 3,210 ft (979 m). Units 1824 are Marker Unit 19 and units 4-6 are Marker Unit 18.

\begin{tabular}{lll}
\hline \hline Unit & Description & Thickness $(\mathrm{cm})$ \\
\hline
\end{tabular}

25 Yellow chalk to top of the outcrop

24 Ferruginous seam
58

0.3

89
86

dark-gray to red-brown clay,

expanded by gypsum,

produces a major reentrant

170

11

3

dark-gray to brown silty

chalk that weathers shaly,

expanded by gypsum and

iron oxide-forms a reentrant

Gray chalk

Ferruginous/gypsiferous seam
Gray chalk

$\begin{array}{ll}3 & \text { Gray chalk-a } 10 \mathrm{~cm} \text { thick } \\ & \text { band of darker gray chalk } \\ & \text { lies } 94 \mathrm{~cm} \text { above bottom } \\ 1 & \text { Bentonite } \\ 1 & \text { Gray chalk }\end{array}$

190 2 91

Total thickness of measured section $1,163.6 \mathrm{~cm}$

Locality 16-Small exposure just south of Twin Butte Creek on line between SE and SW sec. 33, T. 14 S., R. 35 W., Logan County, Kansas. Base at 3,040 ft (927 $\mathrm{m})$.

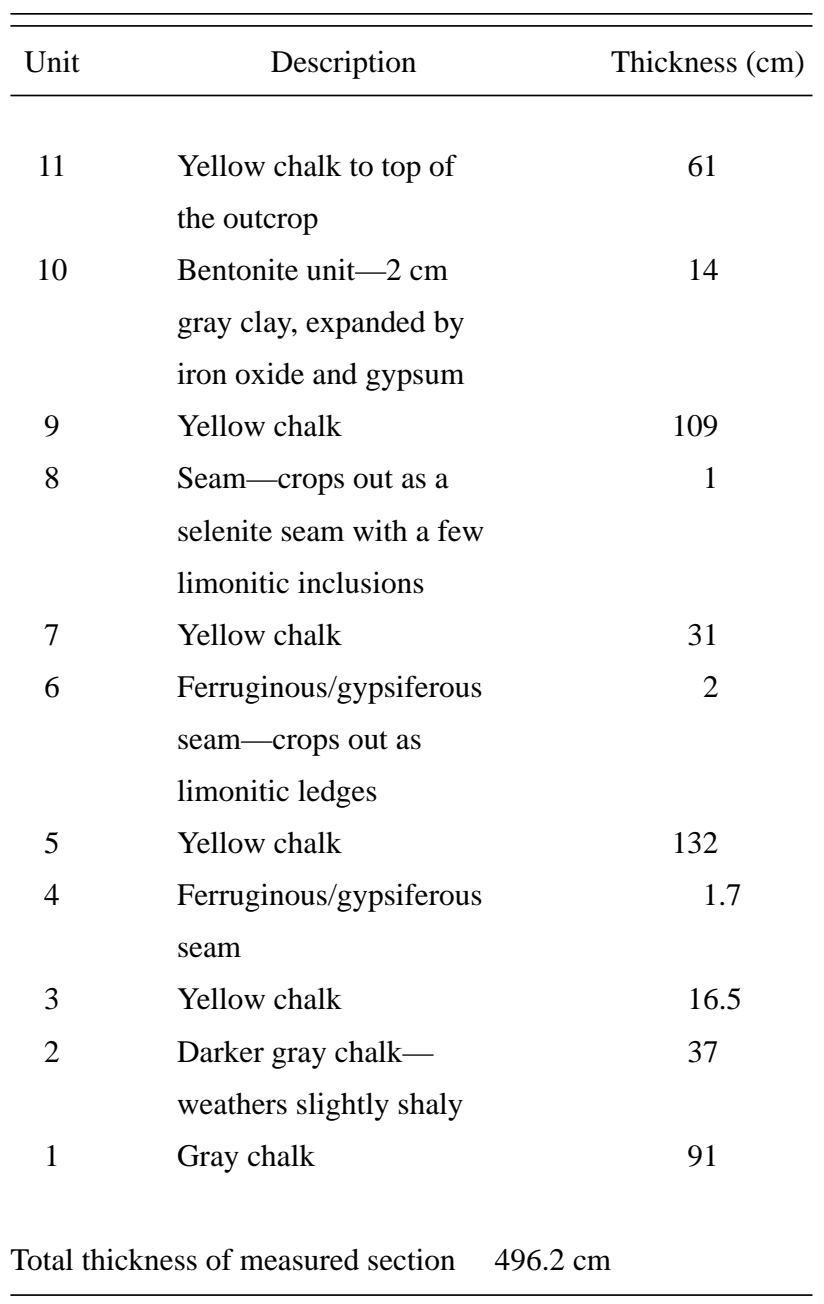


Locality 17-SW sec. 20, T. 14 S., R. 33 W., Logan

County, Kansas. Base at 2,880 ft (878 m). Units 2-4 are Marker Unit 18.

\begin{tabular}{|c|c|c|}
\hline Unit & Description & Thickness (cm) \\
\hline 15 & $\begin{array}{l}\text { Chalk to top of the } \\
\text { outcrop }\end{array}$ & $\sim$ \\
\hline 14 & $\begin{array}{l}\text { Gypsiferous seam-with } \\
\text { gray inclusions, } \\
\text { crops out as selenite ledge }\end{array}$ & 2.5 \\
\hline 13 & Yellow chalk & 256 \\
\hline 12 & $\begin{array}{l}\text { Gypsiferous seam- } \\
\text { crops out as selenite ledge }\end{array}$ & 3.8 \\
\hline 11 & Yellow chalk & 22 \\
\hline 10 & $\begin{array}{l}\text { Gypsiferous seam- } \\
\text { crops out as selenite ledge }\end{array}$ & 3.8 \\
\hline 9 & Yellow chalk & 125 \\
\hline 8 & Bentonite & 3.2 \\
\hline 7 & Chalk & 5.1 \\
\hline 6 & $\begin{array}{l}\text { Seam-produces a } \\
\text { minor reentrant }\end{array}$ & 0.2 \\
\hline 5 & Yellow chalk & 61 \\
\hline 4 & $\begin{array}{l}\text { Bentonite unit- }-8.9 \mathrm{~cm} \\
\text { of pale-gray clay expanded } \\
\text { by iron oxide and gypsum }\end{array}$ & 11.4 \\
\hline 3 & Yellow chalk & 41 \\
\hline 2 & $\begin{array}{l}\text { Bentonite unit_-gray clay } \\
\text { expanded by gypsum and } \\
\text { iron oxide }\end{array}$ & 6.7 \\
\hline 1 & Yellow chalk & 122 \\
\hline \multicolumn{3}{|c|}{ Total thickness of measured section $663.7 \mathrm{~cm}$} \\
\hline
\end{tabular}

Locality 18 - Small outcrop south of Twin Butte Creek in E/2 of SW sec. 13, T. 15 S., R. 34 W., Logan County, Kansas. Base at 2,950 ft (899 m). Unit 8 is Marker Unit 13. (Not illustrated).

\begin{tabular}{lll}
\hline \hline Unit & Description & Thickness (cm) \\
\hline
\end{tabular}

$11 \quad$ Yellow chalk to top of the outcrop

10 Seam-with a few

0.2
9 Yellow chalk—with a

103

few limonitic inclusions, commonly around inoceramids

8 Unit-two ferruginous 5 seams, the upper $0.4 \mathrm{~cm}$ and the lower $0.7 \mathrm{~cm}$ separated by chalk, produces a reentrant

7

Yellow chalk

Ferruginous seam-

locally thickens to $1 \mathrm{~cm}$ or

includes selenite, produces

small limonitic inclusions

5 Yellow chalk-with

numerous Inoceramus

balticus shells

4

Ferruginous seam-

produces many small

limonitic inclusions

3

Yellow chalk

30.5

Seam-invisible in fresh

chalk, but produces limonitic

inclusions where weathered

1 Yellow chalk

Total thickness of measured section $585.9 \mathrm{~cm}$

Locality 19-Little Pyramids, at east end of line between sec. 11 and 14, T. 15 S, R. 33 W., Logan County, Kansas. Base at 2,780 $\mathrm{ft}(848 \mathrm{~m})$. Units 8-9 are probably Marker Unit 9.

\begin{tabular}{lll}
\hline \hline Unit & Description & Thickness (cm) \\
\hline
\end{tabular}

12 Yellow chalk to the top

of the outcrop

11 Seam-visible as a fine

line on outcrop

$10 \quad$ Yellow chalk

170

9 Seam—crops out as a selenite

seam with a few limonitic

inclusions

$8 \quad$ Yellow chalk 71

$7 \quad$ Gray chalk

158

6 Ferruginous/gypsiferous

1

limonitic inclusions

seam 


$\begin{array}{llr}5 & \text { Gray chalk } & 43 \\ 4 & \text { Bentonite } & 1 \\ 3 & \text { Gray chalk } & 31 \\ 2 & \text { Paler, poorly laminated band } & 10 \\ 1 & \text { Gray chalk } & 120\end{array}$

Total thickness of measured section $788.4 \mathrm{~cm}$

Locality 20-SE NE sec. 1, T. 15 S., R. 33 W., Logan County, Kansas. Base at 2,730 ft (832 m).

\begin{tabular}{clc}
\hline \hline Unit & \multicolumn{1}{c}{ Description } & Thickness (cm) \\
\hline 8 & Gray chalk to top of the & 305 \\
& outcrop & \\
7 & Ferruginous/gypsiferous & 1 \\
& seam-produces & \\
& limonitic inclusions & \\
6 & Gray chalk & 47 \\
5 & Bentonite unit-0.4 cm & 1.3 \\
& of gray clay expanded & \\
& by iron oxide and gypsum & 41 \\
4 & Gray chalk & 7.6 \\
3 & Harder, pale-gray band & 1.5 \\
2 & Gray chalk & \\
1 & Ferruginous seam &
\end{tabular}

Locality 21-East end of line between sec. 26 and 35, T. 14 S., R. 33 W., Logan County, Kansas. Base at 2,750 ft (838 m). Units 5-9 are Marker Unit 9.

\begin{tabular}{llc}
\hline \hline Unit & \multicolumn{1}{c}{ Description } & Thickness $(\mathbf{c m})$ \\
\hline \multirow{2}{*}{14} & Yellow chalk to top & 610 \\
& of outcrop & \\
13 & Ferruginous/gypsiferous & 2 \\
& seam & 46 \\
12 & Yellow chalk & 2 \\
11 & Gypsiferous seam & 71 \\
9 & Gray to yellow chalk & 1.5 \\
& Selenite seam-between &
\end{tabular}

$\begin{array}{clc}8 & \text { Gray chalk } & 51 \\ 7 & \text { Paler, poorly laminated chalk } & 13 \\ 6 & \text { Gray chalk } & 38 \\ 5 & \text { Bentonite unit_pale-gray } & 1.3 \\ & \text { clay expanded by iron oxide } \\ 4 & \text { Gray chalk } & 140 \\ 3 & \text { Bentonite } & 0.3 \\ 2 & \text { Gray chalk } & 41 \\ 1 & \text { Ferruginous/gypsiferous } & 0.3 \\ & \text { seam-produces limonitic } & \end{array}$

Total thickness of measured section $1,018.4 \mathrm{~cm}$

Locality 23-Tiny outcrop just north of road on W/2 of line between sec. 18 and 19, T. 13 S., R. 33 W., Logan County, Kansas. Base at 2,900 ft (884 m). Units 1-4 are part of Marker Unit 19.

\begin{tabular}{clc}
\hline \hline Unit & \multicolumn{1}{c}{ Description } & Thickness (cm) \\
\hline 9 & $\begin{array}{l}\text { Massive yellow chalk } \\
\text { to top of the outcrop }\end{array}$ & 51 \\
& Ferruginous seam & 0.5 \\
8 & Massive yellow chalk & 48 \\
7 & Ferruginous seam & 0.5 \\
6 & Massive yellow chalk & 62 \\
5 & Unit-two 0.5 cm & 3.5 \\
4 & ferruginous seams & \\
& separated by chalk & 0.0 \\
3 & Massive yellow chalk & 38 \\
2 & Seam & \\
1 & Massive yellow chalk & \\
Total thickness of measured section & $221.5 \mathrm{~cm}$ \\
\hline
\end{tabular}

Locality 24-Six-Mile Creek just north of two small buttes in W/2 NW sec. 23, T. 13 S., R. 34 W., Logan County, Kansas. Base at 2,940 ft (896 m). Units 1-4 are part of Marker Unit 17, units 26-28 are Marker Unit 18, and units 36-40 are Marker Unit 19.

\begin{tabular}{clc}
\hline \hline Unit & \multicolumn{1}{c}{ Description } & Thickness $(\mathbf{c m})$ \\
\hline 43 & $\begin{array}{l}\text { Yellow chalk to top } \\
\text { of the outcrop }\end{array}$ & $\sim$ \\
& & \\
42 & Ferruginous seam & 0.5 \\
41 & Massive yellow chalk & 66
\end{tabular}


40

Unit-two $0.5 \mathrm{~cm}$ iron

oxide seams separated

by chalk

39

38

37

36

Yellow massive chalk

Seam

Yellow massive chalk

Unit-two ferruginous

and the lower $0.3 \mathrm{~cm}$,

separated by chalk

Seam

Massive yellow chalk

Ferruginous seam-

Yellow chalk

Seam

Yellow chalk

expanded by gypsum

and iron oxide

Gray chalk

Gray chalk

Bentonite

Gray chalk

Gray chalk

as two closely spaced

limonitic ledges

Gray chalk

Seam

Gray chalk

Seam

Gray chalk

Seam

Gray chalk

Bentonite unit- $4.2 \mathrm{~cm}$

of orange material,

expanded by iron oxide

Gray chalk seams, the upper $0.5 \mathrm{~cm}$

Massive yellow chalk-

seams lie at 79,140 , and

$185 \mathrm{~cm}$ above the bottom

produces a sharp reentrant

Bentonite unit $-4 \mathrm{~cm}$ of

tan clay and silty chalk,

Ferruginous/gypsiferous seam

Ferruginous/gypsiferous seam

Bentonite unit—crops out
41

61

$\begin{array}{clr}10 & \text { Ferruginous seam } & 1 \\ 9 & \text { Gray chalk } & 25 \\ 8 & \text { Bentonite unit }-3.5 \mathrm{~cm} & 4.4\end{array}$

$8 \quad$ Bentonite unit $-3.5 \mathrm{~cm}$

of mixed yellow and gray

clay, expanded by iron oxide

Gray chalk 36

Bentonite 2.5

Gray chalk 52

Ferruginous seam $\quad 0.5$

Gray chalk 14

Bentonite 1.5

Gray chalk 91 6
Locality 26-Small area just west of road in NE SE sec. 20, T. 13 S., R. 35 W., Logan County, Kansas. Base at 2,930 ft (893 m). Units 2-10 are Marker Unit 17 and units 12-28 are Marker Unit $\mathrm{H}$.

\begin{tabular}{lll}
\hline \hline Unit & Description & Thickness $(\mathrm{cm})$ \\
\hline
\end{tabular}

30 Tan clay seam-crops $\quad 0.5$

out as a $1.5 \mathrm{~cm}$ selenite

ledge

29 Gray chalk 25

Bentonite $\quad 3.2$

Gray chalk 93

Bentonite unit $-0.9 \mathrm{~cm} \quad 3.5$

of gray clay expanded

by iron oxide

25 Gray chalk 28

24 Ferruginous seam 0.6

23 Gray chalk 23

22 Ferruginous/gypsiferous seam 1.5

21 Gray chalk 19

20 Ferruginous seam 0.6

19 Gray chalk 20

18 Bentonite unit $-2.8 \mathrm{~cm}$

of orange clay expanded

by iron oxide

17 Gray chalk 20

16 Bentonite 1.3

15 Gray chalk 37 


$\begin{array}{ll}14 & \text { Bentonite } \\ 13 & \text { Gray chalk } \\ 12 & \text { Bentonite } \\ 11 & \text { Gray chalk } \\ 10 & \text { Gypsiferous seam-locally } \\ & \text { may contain iron oxide } \\ 9 & \text { Gray chalk } \\ 8 & \text { Ferruginous seam-with } \\ & \text { a few limonitic inclusions } \\ 7 & \text { Gray chalk } \\ 6 & \text { Ferruginous seam-with } \\ & \text { limonitic inclusions } \\ 5 & \text { Gray chalk } \\ 4 & \text { Ferruginous seam—with } \\ & \text { limonitic inclusions } \\ 3 & \text { Gray chalk } \\ 2 & \text { Ferruginous seam } \\ 1 & \text { Gray chalk }\end{array}$

Total thickness of measured section $698.6 \mathrm{~cm}$

Locality 27-W/2 of NW sec. 19, T. 13 S., R. 35 W., Logan County, Kansas. Base at 2,980 ft (909 m). Units 1-4 are part of Marker Unit 19.

\begin{tabular}{|c|c|c|}
\hline Unit & Description & Thickness (cm) \\
\hline 9 & $\begin{array}{l}\text { Yellow chalk to top } \\
\text { of the outcrop }\end{array}$ & 46 \\
\hline 8 & Seam & 0.5 \\
\hline 7 & Massive yellow chalk & 41 \\
\hline 6 & Seam & 0.5 \\
\hline 5 & Massive yellow chalk & 53 \\
\hline 4 & $\begin{array}{l}\text { Unit-two ferruginous } \\
\text { seams, the upper } 0.5 \mathrm{~cm} \\
\text { and the lower } 0.3 \mathrm{~cm} \text { thick, } \\
\text { separated by chalk }\end{array}$ & 3.3 \\
\hline 3 & Yellow chalk & 15 \\
\hline 2 & $\begin{array}{l}\text { Seam-crops out as a } 1-\mathrm{cm} \text {-thick } \\
\text { selenite ledge }\end{array}$ & 0.5 \\
\hline 1 & Yellow chalk & 91 \\
\hline Total & of measured section $250.8 \mathrm{~cm}$ & \\
\hline
\end{tabular}

69

0.5

19

0.5

27

0.8

6.4

0.5

22

0.5

122
Locality 28-Just south of K-25 on line between sec. 27 and 28, T. 13 S., R. 36 W., Logan County, Kansas. Base at 3,070 ft (936 m). Units 14-18 are Marker Unit 19.

17

18

8

7
6
5
4
3
2
1

Yellow chalk to top of the outcrop

Tan seam-crops out as selenite ledge $5 \mathrm{~cm}$ thick

Massive yellow chalk

Tan clay seam-crops out

as selenite ledge

Yellow chalk

69

Dark-tan silty seam—crops

out as selenite ledge

$2.5 \mathrm{~cm}$ thick

Yellow chalk

Gypsiferous seam-crops

out as selenite ledge

$2.5 \mathrm{~cm}$ thick

Yellow chalk

Ferruginous/gypsiferous

seam-crops out as thick

selenite ledge

Yellow chalk

Selenite seam

Yellow chalk

Selenite seam

Chalk-bottom half gray

and top half yellow

Bentonite unit- $2.1 \mathrm{~cm}$ of

pale-gray silty, clay, expanded

by iron oxide and gypsum

Yellow and gray chalk

142

Gypsiferous seam

Chalk

Seam 0.5

Seam 2

Gray and yellow chalk $\quad 31$

1

Chalk $\quad 1.2$

\section{1}

(1)


Locality 29-Small outcrop on south side of the Smoky Hill River in N/2 of SE sec. 24, T. 13 S., R. 37 W., Logan County, Kansas. Base at 3,050 ft $(930 \mathrm{~m})$. Units 10-14 are Marker Unit 19.

\begin{tabular}{|c|c|c|}
\hline Unit & Description & Thickness (cm) \\
\hline 17 & $\begin{array}{l}\text { Yellow chalk to top of } \\
\text { the outcrop }\end{array}$ & 39 \\
\hline 16 & $\begin{array}{l}\text { Ferruginous seam-crops } \\
\text { out as selenite }\end{array}$ & 1 \\
\hline 15 & Yellow chalk & 80 \\
\hline 14 & $\begin{array}{l}\text { Unit-two } 2 \mathrm{~cm} \\
\text { ferruginous seams } \\
\text { separated by chalk }\end{array}$ & 7 \\
\hline 13 & Gray chalk & 22 \\
\hline 12 & Bentonite & 2.9 \\
\hline 11 & Gray chalk & 84 \\
\hline 10 & $\begin{array}{l}\text { Unit-two } 1.5 \mathrm{~cm} \\
\text { ferruginous seams } \\
\text { separated by chalk }\end{array}$ & 5.1 \\
\hline 9 & Gray chalk & 81 \\
\hline 8 & $\begin{array}{l}\text { Ferruginous/gypsiferous } \\
\text { seam-crops out as a } \\
\text { selenite ledge }\end{array}$ & 2.5 \\
\hline 7 & Gray chalk & 201 \\
\hline 6 & $\begin{array}{l}\text { Seam-crops out as a } 2-\mathrm{cm} \\
\text { selenite ledge }\end{array}$ & 0.5 \\
\hline 5 & Gray chalk & 94 \\
\hline 4 & Ferruginous seam & 0.8 \\
\hline 3 & Gray chalk & 38 \\
\hline 2 & $\begin{array}{l}\text { Bentonite unit }-2.8 \mathrm{~cm} \\
\text { of orange clay expanded } \\
\text { by iron oxide }\end{array}$ & 3.8 \\
\hline 1 & Gray chalk & 91 \\
\hline \multicolumn{3}{|c|}{ Total thickness of measured section $753.6 \mathrm{~cm}$} \\
\hline
\end{tabular}

Locality 32-Monument Rocks. NW SW sec. 34, T. 15 S., R. 31 W., Gove County, Kansas. Base at 2,650 ft (808 m). Units 6-8 are Marker Unit 9.

\begin{tabular}{lll}
\hline \hline Unit & Description & Thickness $(\mathrm{cm})$ \\
\hline
\end{tabular}

16 Chalk to top

15 Gray and tan chalk510 with a few bands of paler, poorly laminated chalk

$14 \quad$ Ferruginous/gypsiferous

seam

Gray chalk

Ferruginous/gypsiferous

seam

Gray chalk-a paler band

$10 \mathrm{~cm}$ thick lies $29 \mathrm{~cm}$

above bottom

Ferruginous/gypsiferous

seam

9

Gray chalk

102

8

Bentonite unit $-1.2 \mathrm{~cm}$

of gray clay, expanded by

gypsum and iron oxide

Gray chalk-a paler,

poorly laminated chalk

band $13 \mathrm{~cm}$ thick lies $40 \mathrm{~cm}$

above the bottom

6 Ferruginous/gypsiferous

seam

5

Gray chalk

Ferruginous/gypsiferous

seam

3 Gray chalk

Gypsiferous seam-with

$0.1 \mathrm{~cm}$ iron oxide in the middle

1 Gray chalk
Locality 33-Middle of NE sec. 24, T. 14 S., R. 31 W., Gove County, Kansas. Base at 2,820 ft (860 m). Unit 1 is part of Marker Unit 18 and units $17-19$ are Marker Unit 19.

\begin{tabular}{lll}
\hline \hline Unit & Description & Thickness $(\mathrm{cm})$ \\
\hline
\end{tabular}

20

Chalk to top of

the outcrop

Unit-two ferruginous

seams, the upper $0.8 \mathrm{~cm}$

and the lower $0.2 \mathrm{~cm}$ thick,

separated by chalk, forms

a reentrant

18

Yellow chalk

97 


$\begin{array}{llc}17 & \text { Ferruginous seam } & 0.5 \\ 16 & \text { Yellow chalk } & 75 \\ 15 & \text { Ferruginous seam } & 0.5 \\ 14 & \text { Yellow chalk } & 42 \\ 13 & \text { Ferruginous seam } & 0.5 \\ 12 & \text { Yellow chalk } & 135 \\ 11 & \text { Hard white chalk seam } & 0.5 \\ 10 & \text { Yellow chalk } & 81 \\ 9 & \text { Selenite seam } & 3 \\ 8 & \text { Yellow chalk } & 36 \\ 7 & \text { Bentonite } & 5.1 \\ 6 & \text { Yellow chalk } & 157 \\ 5 & \text { Seam—crops out as } & 1.5 \\ & \text { selenite } & \\ 4 & \text { Yellow chalk } & 9 \\ 3 & \text { Seam—crops out as } & 0.4 \\ & \text { selenite } & 76 \\ 2 & \text { Yellow chalk } & 13 \\ 1 & \text { Bentonite unit—12 cm } \\ & \text { of mixed tan, gray, and } & \\ & \text { very pale gray clays, } \\ & \text { expanded by iron oxide } & \\ & & \\ \text { Total thickness of measured section } & 737.5 \mathrm{~cm} & \\ & & \\ & \end{array}$

Locality 35-Steep south facing cliff in SW SE sec. 20,

T. 14 S., R. 30 W., Gove County, Kansas. Base at

$2,810 \mathrm{ft}(857 \mathrm{~m})$. Units 3-19 are Marker Unit H, units

23-25 are Marker Unit 18, and units 42-45 are

Marker Unit 19.

\begin{tabular}{lll}
\hline \hline Unit & Description & Thickness $(\mathrm{cm})$ \\
\hline
\end{tabular}

$52 \quad$ Yellow chalk to top of

the outcrop

$51 \quad$ Unit- two ferruginous

5.6

seams, the upper $2.5 \mathrm{~cm}$

and the lower $0.5 \mathrm{~cm}$,

separated by chalk

$50 \quad$ Massive yellow chalk

71

49 Seam

0.1

$48 \quad$ Massive yellow chalk

47 Seam

53

0.1

71

4.8 and the lower 0.3 thick,

separated by chalk, produces

a reentrant

Yellow chalk

24

Seam

Yellow chalk

80

White chalk seam

2

Yellow chalk

72

Seam

Yellow chalk

46

Gypsiferous seam

Yellow chalk-a seam

lies $76 \mathrm{~cm}$ above the bottom

Seam

Massive yellow chalk

78

Ferruginous seam

Massive yellow chalk

37

Dark-brown clay seam-

produces a reentrant

Massive yellow chalk

Ferruginous seam

Massive yellow chalk

Seam

Massive yellow chalk

Tan clay seam-produces

a reentrant

Yellow chalk

49

Tan clay seam

Yellow chalk-weathers

orange

Bentonite unit $-2 \mathrm{~cm}$

of gray clay, expanded by iron oxide and gypsum

Massive yellow chalk-a

0.8-cm ferruginous seam lies $108 \mathrm{~cm}$ above the bottom

Ferruginous/gypsiferous seam

Yellow chalk

Bentonite unit $-1.5 \mathrm{~cm}$ of

gray clay expanded by

iron oxide and gypsum

Yellow chalk

Bentonite unit $-0.5 \mathrm{~cm}$ of

gray clay expanded by gypsum

Yellow chalk 


\begin{tabular}{|c|c|c|}
\hline 13 & $\begin{array}{l}\text { Ferruginous/gypsiferous } \\
\text { seam }\end{array}$ & 3.2 \\
\hline 12 & Yellow chalk & 19 \\
\hline 11 & $\begin{array}{l}\text { Ferruginous/gypsiferous } \\
\text { seam }\end{array}$ & 2 \\
\hline 10 & Yellow chalk & 25 \\
\hline 9 & $\begin{array}{l}\text { Bentonite unit- } 2 \mathrm{~cm} \text { of pale-gray } \\
\text { clay, expanded by iron oxide } \\
\text { and gypsum }\end{array}$ & 6 \\
\hline 8 & Yellow chalk & 18 \\
\hline 7 & $\begin{array}{l}\text { Ferruginous/gypsiferous } \\
\text { seam }\end{array}$ & 3 \\
\hline 6 & Yellow chalk & 38 \\
\hline 5 & Bentonite & 2.8 \\
\hline 4 & Yellow chalk & 47 \\
\hline 3 & $\begin{array}{l}\text { Ferruginous/gypsiferous } \\
\text { seam }\end{array}$ & 2.5 \\
\hline 2 & Yellow chalk & 10 \\
\hline 1 & Ferruginous seam & 0.6 \\
\hline
\end{tabular}

Locality 37-Outcrop north of and higher than Monument Rocks in NW SE sec. 28, T. 14 S., R. 31 W., Gove County, Kansas. Base at 2,710 ft (826 m). Units 13-23 are Marker Unit 17.

\begin{tabular}{|c|c|c|}
\hline Unit & Description & Thickness (cm) \\
\hline 34 & $\begin{array}{l}\text { Massive yellow chalk } \\
\text { to top of the outcrop }\end{array}$ & $\sim 100$ \\
\hline 33 & Seam & 0.5 \\
\hline 32 & $\begin{array}{l}\text { Massive yellow chalk- } \\
\text { seams lie at } 10,36 \text {, and } \\
52 \mathrm{~cm} \text { above the bottom }\end{array}$ & 78 \\
\hline 31 & $\begin{array}{l}\text { Unit-two, 1-cm } \\
\text { ferruginous/gypsiferous } \\
\text { seams separated by chalk, } \\
\text { forms a reentrant }\end{array}$ & 6 \\
\hline 30 & Massive yellow chalk & 119 \\
\hline 29 & $\begin{array}{l}\text { Unit-two, } 2.5-\mathrm{cm} \text { brown, } \\
\text { silty seams separated by } \\
\text { soft, dark-tan chalk, produces } \\
\text { a reentrant }\end{array}$ & 7.5 \\
\hline 28 & Massive yellow chalk & 100 \\
\hline 27 & Selenite seam & 2.9 \\
\hline
\end{tabular}

$26 \quad$ Massive yellow chalk 57

Selenite seam 2.9

Massive yellow chalk 47

Seam 0.4

Massive yellow chalk 25

Seam $\quad 0.4$

Massive yellow chalk $\quad 37$

Seam 0.4

Massive yellow chalk 6

Seam 0.4

Massive yellow chalk $\quad 18$

Seam 0.4

Massive yellow chalk 23

Gypsiferous seam—with iron $\quad 0.5$

oxide films at top and bottom

Massive yellow chalk 28

Seam-invisible in fresh chalk, $\quad 0.0$

crops out as a selenite ledge

10 Massive yellow chalk-a $\quad 140$

0.5 -cm seam lies $41 \mathrm{~cm}$

above the bottom

9 Bentonite unit $-4.9 \mathrm{~cm} \quad 10$

of brown clay expanded

by selenite

Yellow chalk 66

Bentonite $\quad 1.8$

Yellow chalk $\quad 52$

Bentonite 3

Yellow chalk 275

Gray chalk 180

Selenite seam 2

Gray chalk 25

Total thickness of measured section $1,315.1$

Locality 38-Small bluff in W/2 of NW sec. 6, T. 15 S., R. 29 W., Gove County, Kansas. Base at 2,660 ft (811 $\mathrm{m})$.

\begin{tabular}{llc}
\hline \hline Unit & \multicolumn{1}{c}{ Description } & Thickness (cm) \\
\hline \multirow{2}{*}{13} & Yellow chalk to top of & \\
& the outcrop & $\sim 300$ \\
12 & Seam & 0.1 \\
11 & Massive yellow chalk & 23
\end{tabular}




\begin{tabular}{|c|c|c|c|c|c|}
\hline 10 & Seam & 0.1 & 31 & Unit-two, 0.3-cm, & 12 \\
\hline 9 & Massive yellow chalk & 38 & & ferruginous seams separated & \\
\hline 8 & Seam & 0.4 & & by $11.4 \mathrm{~cm}$ of chalk $-4 \mathrm{~cm}$ & \\
\hline 7 & Yellow chalk—has lots & 46 & & above the lower seam is a & \\
\hline & of Pseudoperna & & & faint, ferruginous seam & \\
\hline 6 & Soft reddish band- & 7.6 & 30 & Yellow chalk—the upper & 90 \\
\hline & forms a reentrant & & & part is tinged with red & \\
\hline 5 & Yellow chalk—has lots & 81 & 29 & Ferruginous seam & 0.1 \\
\hline & of Pseudoperna & & 28 & Yellow chalk & 97 \\
\hline 4 & Ferruginous seam & 1 & 27 & Ferruginous/selenitic seam- & 0.3 \\
\hline 3 & Yellow chalk—has lots & 83 & & produces a reentrant & \\
\hline & of Pseudoperna & & 26 & Yellow chalk & 55 \\
\hline 2 & Ferruginous seam & 0.5 & 25 & Ferruginous seam- & 0.7 \\
\hline 1 & Yellow chalk & 108 & & produces a reentrant & \\
\hline & & & 24 & Yellow chalk & 7.6 \\
\hline Total t & ess of measured section 688.7 & & 23 & Seam & 0.4 \\
\hline & & & 22 & Yellow chalk & 20 \\
\hline & & & 21 & Seam & 0.4 \\
\hline Local & 2-Small butte in SW NW & 35, T. 13 S., R. & 20 & Yellow chalk & 35 \\
\hline & Gove County, Kansas. Base &, $770 \mathrm{ft}(845$ & 19 & Seam & 0.4 \\
\hline m) & its $15-21$ are Marker Unit 1 & d units 42-49 & 18 & Yellow chalk & 17 \\
\hline & & & 17 & Seam & 0.4 \\
\hline Unit & Description & Thickness (cm) & 16 & Yellow chalk & 9 \\
\hline & & & 15 & Ferruginous clay seam & 2 \\
\hline 50 & Yellow chalk to top of & $\sim$ & 14 & Yellow chalk & 141 \\
\hline & the outcrop & & 13 & Ferruginous clay seam- & 1 \\
\hline 49 & Seam & 0.4 & & produces a reentrant & \\
\hline 48 & Yellow chalk & 28 & 12 & Yellow chalk & 32 \\
\hline 47 & Seam & 0.4 & 11 & Ferruginous seam & 0.5 \\
\hline 46 & Yellow chalk & 25 & 10 & Yellow chalk & 9.5 \\
\hline 45 & Seam & 0.4 & 9 & Ferruginous seam & 0.1 \\
\hline 44 & Yellow chalk & 10 & 8 & Yellow chalk & 60 \\
\hline 43 & Seam & 0.4 & 7 & Ferruginous seam & 0.1 \\
\hline 42 & Yellow chalk & 31 & 6 & Yellow chalk & 77 \\
\hline 41 & Seam & 0.4 & 5 & Ferruginous seam & 0.1 \\
\hline 40 & Yellow chalk & 85 & 4 & Yellow chalk & 61 \\
\hline 39 & Ferruginous seam- & 2.5 & 3 & Clay seam & 1.5 \\
\hline & produces a $8.9-\mathrm{cm}$ reentrant & & 2 & Yellow chalk & 86 \\
\hline 38 & Yellow chalk & 78 & 1 & Ferruginous seam & 0.2 \\
\hline 37 & Seam & 0.5 & & & \\
\hline 36 & Yellow chalk & 47 & Total t & ess of measured section 1,209 & \\
\hline 35 & Seam & 0.4 & & & \\
\hline 34 & Yellow chalk & 25 & & & \\
\hline 33 & Seam & 0.4 & & & \\
\hline 32 & Yellow chalk & 57 & & & \\
\hline
\end{tabular}


Locality 44-Small outcrop in NW SW sec. 32, T. 12 S., R. 28 W., Gove County, Kansas. Base at 2,640 ft (805 $\mathrm{m})$. Units 1-11 are part of Marker Unit $\mathrm{H}$.

\begin{tabular}{|c|c|}
\hline Unit & Description \\
\hline 18 & $\begin{array}{l}\text { Massive yellow chalk to } \\
\text { the top of the outcrop }\end{array}$ \\
\hline 17 & Clay seam \\
\hline 16 & Massive yellow chalk \\
\hline 15 & Soft orange chalk \\
\hline 14 & $\begin{array}{l}\text { Massive yellow chalk- } \\
\text { forms ledge }\end{array}$ \\
\hline 13 & Ferruginous seam \\
\hline 12 & Yellow massive chalk \\
\hline 11 & Seam-locally selenitic \\
\hline 10 & Yellow chalk \\
\hline 9 & $\begin{array}{l}\text { Clay seam—crops out as } \\
\text { ferruginous ledge }\end{array}$ \\
\hline 8 & Yellow chalk \\
\hline 7 & Bentonite \\
\hline 6 & Yellow chalk \\
\hline 5 & Ferruginous seam \\
\hline 4 & Yellow chalk \\
\hline 3 & Ferruginous seam \\
\hline 2 & Yellow chalk \\
\hline 1 & $\begin{array}{l}\text { Bentonite unit- }-0.6 \mathrm{~cm} \\
\text { of gray clay, expanded } \\
\text { by iron oxide }\end{array}$ \\
\hline
\end{tabular}

Total thickness of measured section $891.1 \mathrm{~cm}$

Locality 45-West side of small butte at the end of long bluff, in S/2 of SE sec. 15, T. 13 S., R. 28 W., Gove County, Kansas. Base at 2,600 ft (793 m). Units 812 are Marker Unit 16, units 18-22 are Marker Unit 17, and units 24-28 are Marker Unit H.

\begin{tabular}{llc}
\hline \hline Unit & \multicolumn{1}{c}{ Description } & Thickness (cm) \\
\hline 39 & $\begin{array}{l}\text { Massive yellow chalk to } \\
\text { the top of the outcrop }\end{array}$ & 668 \\
38 & $\begin{array}{l}\text { Bentonite unit-1.4 cm of } \\
\text { gray clay, expanded by } \\
\text { gypsum and iron oxide, crops }\end{array}$
\end{tabular}

out as two selenitic seams

in a reentrant

Yellow chalk

41

Gypsiferous seam 2

Yellow chalk 26

Bentonite $\quad 3.5$

Yellow chalk 27

Bentonite unit $-1.4 \mathrm{~cm}$ of $\quad 2.5$

brownish-tan clay, expanded

by gypsum and iron oxide

Yellow chalk 30

Bentonite 6

Yellow chalk-the top $6 \mathrm{~cm} \quad 28$

are silty and soft

Ferruginous/gypsiferous seam $\quad 2.5$

Yellow chalk-the bottom 53

half is granular, paler, and

forms a rounded resistant ledge

Bentonite unit $-2.6 \mathrm{~cm}$ of pale-gray

clay, expanded by iron oxide

and gypsum

Gray and yellow chalk $\quad 66$

Bentonite $\quad 3.8$

Gray chalk $\quad 100$

Ferruginous/gypsiferous seam 2

Gray chalk 20

Ferruginous/gypsiferous seam 2

Gray chalk 38

Bentonite

Gypsiferous seam—crops out

Chalk

gray-green clay, expanded by

iron oxide and gypsum

Gray chalk

Gypsiferous seam 2

Gray chalk 57 


$\begin{array}{llc}4 & \text { Bentonite } & 4.4 \\ 3 & \text { Gray chalk } & 23 \\ 2 & \text { Gypsiferous seam } & 2 \\ 1 & \text { Gray chalk } & 122\end{array}$

Total thickness of measured section $1,831.4 \mathrm{~cm}$

Locality 47-Outcrop near bottom of draw in NE SW sec. 11, T. 13 S., R. 29 W., Gove County, Kansas. Base at 2,660 ft $(811 \mathrm{~m})$. Units $1-8$ are Marker Unit 17 and units 18-30 are Marker Unit H.

\begin{tabular}{lcc}
\hline \hline Unit & Description & Thickness (cm) \\
\hline
\end{tabular}

$40 \quad$ Massive yellow chalk to top of the outcrop

39

$$
\text { Seam }
$$

Yellow chalk

Seam

Yellow chalk

Seam

Yellow chalk

Soft tan chalk-forms

a reentrant

Ferruginous seam

Yellow chalk

Ferruginous/gypsiferous seam

Yellow chalk

Seam

Yellow chalk

Seam

Yellow chalk

Ferruginous/gypsiferous seam

Yellow chalk

Ferruginous seam-locally

expanded to $3.8 \mathrm{~cm}$

Yellow chalk-a $1 \mathrm{~cm}$

gypsiferous seam lies 12.7

$\mathrm{cm}$ down from the top

Ferruginous/gypsiferous seam

Gray and yellow chalk

Ferruginous/gypsiferous seam

Yellow chalk

Ferruginous/gypsiferous seam

Gray to yellow chalk

$\begin{array}{cl}14 & \text { Gypsiferous seam } \\ 13 & \text { Gray chalk } \\ 12 & \text { Gypsiferous seam } \\ 11 & \text { Gray chalk } \\ 10 & \text { Ferruginous/gypsiferous seam } \\ 9 & \text { Yellow chalk } \\ 8 & \text { Ferruginous/selenitic seam } \\ 7 & \text { Yellow chalk } \\ 6 & \text { Ferruginous/selenitic seam } \\ 5 & \text { Chalk } \\ 4 & \text { Gypsiferous seam } \\ 3 & \text { Chalk } \\ 2 & \text { Ferruginous seam } \\ 1 & \text { Gray chalk }\end{array}$

0.6

9

0.6

97

2.5

16.5

1.2

29

1.2

18

0.6

7

0.5

30.5

Total thickness of measured section $1,115 \mathrm{~cm}$

Locality 51-N/2 of SE sec. 13, T. 13 S., R. 30 W., Gove County, Kansas. Base at 2,740 ft $(835 \mathrm{~m})$. Units 214 are Marker Unit $\mathrm{H}$.

\begin{tabular}{lll}
\hline \hline Unit & Description & Thickness $(\mathrm{cm})$ \\
\hline
\end{tabular}

of the outcrop

16 Reddish-tan clay seam

Ferruginous/gypsiferous seam

Yellow chalk

Ferruginous/gypsiferous seam

Yellow chalk

Ferruginous/gypsiferous seam

Yellow chalk

Ferruginous/gypsiferous seam

Yellow chalk

Bentonite unit $-4.4 \mathrm{~cm}$ of

orange clay expanded by

gypsum, produces a major

reentrant
Chalk

Ferruginous/gypsiferous seam

Chalk

Gypsiferous seam

Gray chalk 
Locality 54-Small exposure just south of the road in NE 1/4 of SW 1/4, Sec. 22, T. 8 S., R. 24 W., Graham County, Kansas. Base at 2,250 ft (686 m). Units 410 are Marker Unit 17 and units 14-28 are Marker Unit $\mathrm{H}$.

\begin{tabular}{|c|c|c|c|c|c|}
\hline Unit & Description & Thickness (cm) & 4 & Ferruginous/gypsiferous s & 0.6 \\
\hline & & & 3 & Gray chalk & 128 \\
\hline \multirow[t]{2}{*}{39} & Massive yellow chalk to & 51 & 2 & Ferruginous/gypsiferous s & 0.5 \\
\hline & top of the outcrop & & 1 & Gray chalk & 122 \\
\hline 38 & Ferruginous seam & 0.3 & & & \\
\hline 37 & Massive yellow chalk & 27 & \multicolumn{3}{|c|}{ Total thickness of measured section $884.5 \mathrm{~cm}$} \\
\hline 36 & Ferruginous seam & 0.1 & & & \\
\hline 35 & Massive yellow chalk & 29 & & & \\
\hline 34 & Ferruginous seam & 0.1 & \multirow{3}{*}{\multicolumn{3}{|c|}{$\begin{array}{l}\text { Locality 55-Small outcrop on east side of small draw in } \\
\text { N/2 of SW sec. 13, T. } 8 \text { S., R. } 24 \text { W., Graham County, } \\
\text { Kansas. Base at 2,240 ft (683 m). Units 17-19 are } \\
\text { Marker Unit } 18 .\end{array}$}} \\
\hline 33 & Massive yellow chalk & 11 & & & \\
\hline 32 & Ferruginous seam & 0.1 & & & \\
\hline 31 & Yellow chalk & 32 & & & \\
\hline 30 & Bentonite & 2.9 & Unit & Description & Thickness (cm) \\
\hline \multirow[t]{3}{*}{29} & Yellow chalk—a $0.1-\mathrm{cm}$ & 92 & & & \\
\hline & ferruginous seam lies $41 \mathrm{~cm}$ & & 30 & Yellow chalk & 114 \\
\hline & above the bottom & & 29 & Seam & 0.4 \\
\hline 28 & Ferruginous/gypsiferous seam & 3.4 & 28 & Yellow chalk & 62 \\
\hline \multirow[t]{3}{*}{27} & Yellow chalk—bottom & 31 & 27 & Ferruginous seam & 0.4 \\
\hline & $10 \mathrm{~cm}$ is softer and produces & & 26 & Massive yellow chalk & 28 \\
\hline & a reentrant & & 25 & Ferruginous seam & 1.5 \\
\hline 26 & Ferruginous/gypsiferous seam & 1 & 24 & Massive yellow chalk & 132 \\
\hline 25 & Yellow chalk & 22 & 23 & Pale-gray clay seam & 2 \\
\hline 24 & Tan ferruginous seam & 0.6 & 22 & Yellow chalk & 5.6 \\
\hline 23 & Yellow chalk & 22 & 21 & Ferruginous seam & 0.2 \\
\hline 22 & Grayish-tan clay seam & 1.5 & 20 & Yellow chalk & 63 \\
\hline 21 & Yellow chalk & 22 & 19 & Bentonite & 10 \\
\hline 20 & Bentonite & 3.9 & 18 & Yellow chalk & 52 \\
\hline 19 & Yellow chalk & 18 & 17 & Bentonite & 5.7 \\
\hline 18 & Reddish-tan clay seam & 2 & 16 & Yellow chalk-a 0.2-cm & 109 \\
\hline 17 & Yellow chalk & 36 & & ferruginous seam lies in & \\
\hline 16 & Reddish-tan clay seam & 2.5 & & the middle & \\
\hline 15 & Yellow chalk & 56 & 15 & White chalk seam & 0.2 \\
\hline 14 & Bentonite & 2.9 & 14 & Yellow chalk & 36 \\
\hline 13 & Yellow chalk & 10 & 13 & Dark-tan clay seam & 2 \\
\hline 12 & Bentonite & 1.5 & 12 & Soft yellow chalk & 150 \\
\hline 11 & Gray chalk & 77 & 11 & Massive yellow chalk- & 23 \\
\hline 10 & Ferruginous/gypsiferous seam & 2 & & forms a resistant ledge & \\
\hline 9 & Gray chalk & 18 & 10 & Ferruginous seam & 0.2 \\
\hline 8 & Ferruginous/gypsiferous seam & 2 & 9 & Massive yellow chalk & 28 \\
\hline 7 & Gray chalk & 24 & 8 & Seam & 0.1 \\
\hline
\end{tabular}

Unit-two ferruginous/ $\quad 4.6$ gypsiferous seams, the upper $1 \mathrm{~cm}$ and the lower $1.6 \mathrm{~cm}$ thick, separated by chalk 


\begin{tabular}{|c|c|c|c|c|c|}
\hline 7 & Massive yellow chalk & 26 & \multirow{2}{*}{$\begin{array}{l}17 \\
16\end{array}$} & Ferruginous seam & 0.6 \\
\hline 6 & Seam & 0.1 & & Yellow chalk & 20 \\
\hline 5 & Massive yellow chalk & 10 & 15 & Ferruginous seam & 0.5 \\
\hline 4 & Seam & 0.1 & 14 & Yellow chalk & 6.7 \\
\hline 3 & Massive yellow chalk & 33 & 13 & Bentonite & 2 \\
\hline 2 & Ferruginous seam & 2 & 12 & Yellow chalk & 81 \\
\hline \multirow[t]{2}{*}{1} & \multirow[t]{2}{*}{ Yellow chalk } & \multirow[t]{2}{*}{91} & 11 & Seam & 0.1 \\
\hline & & & 10 & Yellow chalk & 69 \\
\hline \multicolumn{3}{|c|}{ Total thickness of measured section $\quad 935.5 \mathrm{~cm}$} & 9 & Bentonite & 2.9 \\
\hline \multirow{6}{*}{\multicolumn{3}{|c|}{$\begin{array}{l}\text { Locality } 60 \text { - Just north of road and west of oil well at } \\
\text { center of line between sec. } 6 \text { and 7, T. } 8 \text { S., R. } 23 \text { W., } \\
\text { Graham County, Kansas. Base at 2,250 ft }(686 \mathrm{~m}) \text {. } \\
\text { Units 13-17 are Marker Unit } 16 .\end{array}$}} & 8 & Yellow chalk & 31 \\
\hline & & & 7 & Ferruginous seam & 0.2 \\
\hline & & & 6 & Yellow chalk & 24 \\
\hline & & & 5 & Ferruginous seam & 0.1 \\
\hline & & & 4 & Gray chalk & 342 \\
\hline & & & 3 & Ferruginous/gypsiferous seam & 1.2 \\
\hline Unit & Description & Thickness (cm) & 2 & Gray chalk & 84 \\
\hline & & & 1 & Bentonite & 5.1 \\
\hline 45 & Indistinct ferruginous seam & 1 & \multirow{2}{*}{\multicolumn{3}{|c|}{ Total thickness of measured section $\quad 1,080.3 \mathrm{~cm}$}} \\
\hline 44 & Yellow chalk & 34 & & & \\
\hline 43 & Bentonite & 1.9 & \multirow{5}{*}{\multicolumn{3}{|c|}{$\begin{array}{l}\text { Locality 64-SW sec. 21, T. } 8 \text { S., R. } 24 \text { W., Graham } \\
\text { County, Kansas. Base at 2,280 ft (695 m). Units 3-9 } \\
\text { are Marker Unit 20. (Not illustrated.) }\end{array}$}} \\
\hline 42 & Yellow chalk & 35 & & & \\
\hline 41 & Bentonite & 2 & & & \\
\hline 40 & Yellow chalk & 9.5 & & & \\
\hline 39 & Soft tan clay seam & 0.3 & & & \\
\hline 38 & Yellow chalk & 16.5 & \multirow[t]{2}{*}{ Unit } & \multirow[t]{2}{*}{ Description } & Thickness (cm) \\
\hline 37 & Seam & 0.0 & & & \\
\hline 36 & Yellow chalk & 36 & 14 & Chalk to top of the outcrop & $\sim$ \\
\hline 35 & Ferruginous seam & 0.3 & 13 & Seam & 0.5 \\
\hline 34 & Yellow chalk & 13.3 & 12 & Yellow chalk & 16.5 \\
\hline 33 & Ferruginous seam & 0.4 & 11 & Ferruginous seam & 0.1 \\
\hline 32 & Yellow chalk & 11.4 & 10 & Massive yellow chalk & 145 \\
\hline 31 & Bentonite & 2.2 & 9 & Ferruginous seam & 0.5 \\
\hline 30 & Yellow chalk & 14 & 8 & Massive yellow chalk & 28 \\
\hline 29 & Ferruginous seam & 0.1 & 7 & Ferruginous seam & 0.5 \\
\hline 28 & Yellow chalk & 4.4 & 6 & Massive yellow chalk & 47 \\
\hline 27 & Ferruginous seam & 0.5 & 5 & Bentonite unit—waxy tan & 1.5 \\
\hline 26 & Yellow chalk & 104 & & clay between films of & \\
\hline 25 & Ferruginous seam & 0.1 & & iron oxide & \\
\hline 24 & Pale-yellow chalk & 3.5 & 4 & Yellow chalk & 1.5 \\
\hline 23 & Ferruginous seam & 0.3 & 3 & Ferruginous seam & 1.5 \\
\hline 22 & Yellow chalk & 56 & 2 & Yellow chalk & 67 \\
\hline 21 & Bentonite & 2.5 & 1 & Ferruginous seam & 0.5 \\
\hline 20 & Yellow chalk & 23 & & & \\
\hline 19 & Red-tan clay seam & 0.7 & Total tl & ess of measured section 310 . & \\
\hline
\end{tabular}


Locality 72-West side of drainage in NW SW sec. 24, T.

14 S., R. 31 W., Gove County Base at 2,740 ft (835 m).

Units 4-5 are Marker Unit 15.

\begin{tabular}{|c|c|c|}
\hline Unit & Description & Thickness (cm) \\
\hline 18 & $\begin{array}{l}\text { Resistant yellow chalk- } \\
\text { forms a cap on outcrop }\end{array}$ & 100 \\
\hline 17 & $\begin{array}{l}\text { Ferruginous seam- } \\
\text { in } 25-\mathrm{cm} \text { reentrant }\end{array}$ & 0.2 \\
\hline 16 & Massive yellow chalk & 120 \\
\hline 15 & $\begin{array}{l}\text { Soft yellow chalk-forms } \\
\text { a reentrant }\end{array}$ & 6.5 \\
\hline 14 & $\begin{array}{l}\text { Massive yellow chalk- } \\
\text { a } 0.2-\mathrm{cm} \text { ferruginous seam } \\
\text { lies } 90 \mathrm{~cm} \text { above the bottom }\end{array}$ & 132 \\
\hline 13 & $\begin{array}{l}\text { Bentonite unit }-2.5 \mathrm{~cm} \text { of gray } \\
\text { clay expanded by iron oxide }\end{array}$ & 6 \\
\hline 12 & $\begin{array}{l}\text { Yellow chalk-a seam lies } \\
89 \mathrm{~cm} \text { above the bottom }\end{array}$ & 183 \\
\hline 11 & Bentonite & 2.5 \\
\hline 10 & Yellow chalk & 242 \\
\hline 9 & Ferruginous/gypsiferous seam & 1.8 \\
\hline 8 & Yellow chalk & 12.5 \\
\hline 7 & Ferruginous/gypsiferous seam & 2.5 \\
\hline 6 & Gray chalk & 155 \\
\hline 5 & Bentonite & 2.5 \\
\hline 4 & $\begin{array}{l}\text { Paler granular chalk-a seam } \\
\text { lies } 34 \mathrm{~cm} \text { above the bottom }\end{array}$ & 54 \\
\hline 3 & Gray chalk & 500 \\
\hline 2 & Ferruginous/gypsiferous seam & 2.5 \\
\hline 1 & Gray chalk & 100 \\
\hline \multicolumn{3}{|c|}{ Total thickness of measured section $\quad 1,623.0 \mathrm{~cm}$} \\
\hline
\end{tabular}

